University of New Hampshire

University of New Hampshire Scholars' Repository

10-2012

\title{
The quantitative soil pit method for measuring belowground carbon and nitrogen stocks
}

\author{
Matthew A. Vadeboncoeur \\ University of New Hampshire, matt.vad@unh.edu \\ Steven P. Hamburg \\ Environmental Defense Fund \\ Joel D. Blum \\ University of Michigan \\ Michael J. Pennino \\ University of Maryland - Baltimore County \\ Ruth D. Yanai \\ SUNY College of Environmental Science and Forestry \\ Follow this and additional works at: https://scholars.unh.edu/ersc \\ next page for additional authors \\ Part of the Ecology and Evolutionary Biology Commons, and the Forest Sciences Commons

\section{Comments} \\ This record is for the author's post print version of this work. URL for the publisher's version: https://www.soils.org/ \\ publications/sssaj/abstracts/76/6/2241\#
}

\section{Recommended Citation}

Vadeboncoeur MA, Hamburg SP, Blum JD, Pennino MJ, Yanai RD, Johnson CE. 2012. The quantitative soil pit method for measuring belowground carbon and nitrogen stocks. Soil Science Society of America Journal 76: 2241-2255

This Article is brought to you for free and open access by the Institute for the Study of Earth, Oceans, and Space (EOS) at University of New Hampshire Scholars' Repository. It has been accepted for inclusion in Earth Systems Research Center by an authorized administrator of University of New Hampshire Scholars' Repository. For more information, please contact Scholarly.Communication@unh.edu. 


\section{Authors}

Matthew A. Vadeboncoeur, Steven P. Hamburg, Joel D. Blum, Michael J. Pennino, Ruth D. Yanai, and Chris E. Johnson 


\title{
The Quantitative Soil Pit Method for Measuring Belowground Carbon and Nitrogen Stocks
}

\author{
Matthew A. Vadeboncoeur \\ University of New Hampshire
}

Steven P. Hamburg

Environmental Defense Fund

Joel D. Blum

University of Michigan

Michael J. Pennino

University of Maryland

Ruth D. Yanai

SUNY College of Environmental Science and Forestry

Chris E. Johnson

Syracuse University

\begin{abstract}
Many important questions in ecosystem science require estimates of stocks of soil carbon and nutrients. Quantitative soil pits provide direct measurements of total soil mass and elemental content in depth-based samples representative of large volumes, bypassing potential errors associated with independently measuring soil bulk density, rock volume, and elemental concentrations. The method also allows relatively unbiased sampling of other belowground carbon and nutrient stocks, including roots, coarse organic fragments, and rocks. We present a comprehensive methodology for sampling these pools with quantitative pits and assess their accuracy, precision, effort, and sampling intensity as compared to other methods. At 14 forested sites in New Hampshire, non-soil belowground pools (which other methods may omit, double-count, or undercount) accounted for upwards of $25 \%$ of total belowground $\mathrm{N}$ and $\mathrm{C}$ stocks: coarse material accounted for $4 \%$ and $1 \%$ of $\mathrm{C}$ and $\mathrm{N}$ in the $\mathrm{O}$ horizon; roots were $11 \%$ and $4 \%$ of $C$ and $N$ in the $O$ horizon and $10 \%$ and $3 \%$ of $C$ and $N$ in the $B$ horizon; and soil adhering to rocks represented $5 \%$ of total $B$-horizon $C$ and $N$. The top $50 \mathrm{~cm}$ of the $C$ horizon contained the equivalent of $17 \%$ of B-horizon C and N. Sampling procedures should be carefully designed to avoid treating these important pools inconsistently. Quantitative soil pits have fewer sources of systematic error than coring methods; the main disadvantage is that because they are time-consuming and create a larger zone of disturbance, fewer observations can be made than with cores.
\end{abstract}

This reformatted accepted manuscript is made available by the authors following an 18 month post-publication embargo period, in accordance with SSSA copyright policy.

The original publication is available from SSSA; http://dx.doi.org/10.2136/sssaj2012.0111

This document should be cited as:

Vadeboncoeur, M.A., S.P. Hamburg, J.D. Blum, M.J. Pennino, R.D. Yanai, and C.E. Johnson. 2012. The quantitative soil pit method for measuring belowground carbon and nitrogen stocks. Soil Science Society of America Journal 76:2241-2255. 


\section{Introduction}

Estimating belowground stocks of carbon, nutrients, and pollutants is critical to understanding ecosystem responses to changes in land use, forest management, climate, and other environmental stresses. Soil is an important and dynamic component of the carbon cycle, and more accurately quantifying changes in soil and non-soil belowground carbon stocks is necessary to improve global change models and to predict the effects of land-based mitigation activities (Nave et al., 2010; Schmidt et al., 2011).

The most common methods of sampling soils involve augers, corers, or the sampling of soil horizons from profiles exposed by excavation (Tan, 1996; Boone et al., 1999; Bélanger and van Rees, 2008). In soils that have been well mixed vertically and horizontally, augers and corers (push and hydraulic) provide representative plow-layer samples, and coring a known volume can yield an accurate estimate of bulk density, allowing chemical concentrations to be converted to content to the sampled depth (Ellert et al., 2008). Such methods are less satisfactory in heterogeneous soils, particularly on rocky, uneven terrain with a high degree of small-scale spatial variation in soil development, disturbance, horizon depth, and rock content. While soil cores are often used in such systems, variance is typically high and there may be large systematic biases related to the inability to sample below rocks larger than the corer (Harrison et al., 2003; Park et al., 2007). Recent work (e.g. Diochon et al., 2009; Harrison et al., 2011; Lorenz et al., 2011) emphasizes the potential importance of changes in the often unsampled "deep" (>20 cm) soil horizons in ecosystem C balances, especially following disturbance.

For these reasons, rocky forest soils are often sampled by excavating pits and sampling from an exposed profile, usually by genetic horizon (e.g. Bailey et al., 2005). Bulk density is then measured at various depths with push-cores or by measuring the mass and volume of individual clods, while coarse fraction is estimated visually on exposed walls of the pit. This method allows for deeper sampling, more accurate assessment of bulk density and coarse fraction, and better recognition of genetic horizons than is possible with coring. However, it is not the best way to estimate soil mass or nutrient contents because of the difficulty of estimating rock volume.
Lyford (1964), citing earlier direct measurements of coarse fraction (Donahue, 1940; Bethlahmy, 1952), excavated rectangular access pits and quantitatively removed soils from a known adjacent volume. All material was sorted by size class and weighed, allowing direct measurement of coarse fraction and soil mass by horizon from a large representative volume. Hamburg (1984a,b) adapted Lyford's quantitative approach, excavating $0.5-1.0 \mathrm{~m}^{2}$ soil pits volumetrically by depth increment, and weighing soil and coarse fragments in the field. Soil was then subsampled for the determination of moisture, organic matter, and elemental concentrations. The major advantage of this method is the direct measurement of the mass of each soil layer, rather than calculating it from estimates of bulk density and coarse fraction. Like other pit methods, quantitative pits are a substantial improvement over cores, because there are fewer locations that cannot be sampled due to the presence of rocks. Deep soil horizons are also more accessible to pit methods than to coring methods, and large, representative samples can be taken with little contamination from surficial horizons. This method has been used in at least 40 studies totaling over 1100 pits (Appendix).

Here, we use the quantitative pit method to conduct a comprehensive accounting of belowground $\mathrm{C}$ and $\mathrm{N}$ pools to the bottom of the $\mathrm{B}$ horizon across 14 northern hardwood forest stands in the White Mountain region of New Hampshire. In addition to total soil $\mathrm{C}$ and $\mathrm{N}$, we quantified stocks in roots, coarse organic fragments, the top $50 \mathrm{~cm}$ of the underlying $\mathrm{C}$ horizon, and the soil adhering to rocks. We also review variations in quantitative pit methodology across published studies, summarize published mean and variance data for soil mass, $\mathrm{C}$ content, and root mass, and calculate statistical power and detectable change statistics. We intend our results to serve as a guide in designing future sampling efforts, particularly those intended to detect stock changes over time.

\section{Methods and Data}

\section{Study sites}

We sampled 14 forested sites in the White Mountain region of New Hampshire (Figure 1), between 320 and 630 m elevation. The most common soils were isotic, frigid Haplorthods developed on rocky ablation till derived from local granitic and metamorphic bedrock, and varying in texture from 
sandy loam to loamy sand. Six of the sites (" $M$ " and " $H$ " sites) sampled in 2003 had been previously sampled for forest floor mass and chemistry, and represent a range of northern hardwood stand ages following cutting (Yanai et al., 2000). Two other sites sampled in 2003 were a pasture (B1) and a woodlot (BW), abandoned in the 1940's (Hamburg, 1984b; Rhoads, 2005), now dominated by mature northern hardwoods mixed with spruce and hemlock, respectively. Six additional sites in the Bartlett Experimental Forest (" $C$ " sites) were sampled in 2004 and also represent a range of northern hardwood stand ages following cutting (14-120 years; Park et al. 2007).

\section{Field Methods}

Three quantitative soil pits were excavated at each of the 14 sites for the purpose of quantifying belowground stocks of carbon and nutrients. We updated the method developed by Hamburg (1984a,b), modified by Huntington et al. (1988), and adopted widely (Appendix). The method was modified to allow a more comprehensive accounting of a variety of belowground $\mathrm{C}$ and $\mathrm{N}$ stocks, and to provide samples for other analyses, including weathering profiles (Schaller et al., 2010).

\section{Site selection and preparation}

At each forest stand studied, the three replicate pits were located randomly, stratified among forest inventory subplots or transects. Study sites ranged in area from 0.25-1.0 ha; mean distance between pits within a site was approximately $50 \mathrm{~m}$. We examined random candidate pit locations, choosing the first that satisfied all of the following criteria:

- Pit center was not within $50 \mathrm{~cm}$ of a tree $>10 \mathrm{~cm}$ in diameter at breast height $(\mathrm{DBH})$

- Pit area $\left(0.5 \mathrm{~m}^{2}\right)$ had $<50 \%$ coverage of surface rock

- There was no obvious recent soil disturbance (e.g. tip-ups, skid trails) in or adjacent to the pit footprint

- At least three steel rods, including two on opposite sides of the pit, could be driven sufficiently deep into the soil to firmly secure the wooden reference frame

- Microtopography allowed the reference frame to sit securely against the soil surface.

All together, approximately $30 \%$ of the candidate locations were rejected and relocated. Of these, most rejections were due to large rocks at or near the surface that prevented securing the frame adequately.

Aboveground woody debris and vegetation, including trees $<10 \mathrm{~cm} \mathrm{DBH}$, were removed from the pit footprint before securing the frame. Fine woody debris not covered by leaf litter was clipped and discarded. We defined woody debris fully covered by leaf litter as a belowground stock. A square wooden frame with an interior area of $0.5 \mathrm{~m}^{2}$ (70.7 $\mathrm{cm}$ on a side) was secured to the ground by driving lengths of $1 / 2$ " rebar through pre-drilled holes and securing U-clamps against the frame. A grid of 25 measurement points and a ruler were used to measure the perpendicular depth to the top of the 0 horizon from the top surface of the frame, which served as an immobile reference plane throughout the excavation.

\section{O horizon excavation}

Relatively little attention was given to sampling fine roots early in the use of this method (Hamburg 1984b; Huntington 1988). In our 2003 soil pits, we dried and forcefully sieved the Oi and Oe horizons, which were collected as a single sample (hereafter "Oie"), resulting in a single sample of fragmented litter and roots. Picking root fragments from this material was extremely labor-intensive even for small subsamples. In 2004, we subsampled the Oie by securing three $10-\mathrm{cm}$ square blocks to the forest floor with long nails, carefully cutting around them with a finely serrated knife, and leaving them in place as we removed the remainder of the Oie by hand and with clippers, before bagging and weighing in the field. Subsamples under the blocks were bagged separately to be picked for fine roots (Park et al., 2007).

The Oa horizon was removed with stainless steel trowels and clippers, taking care to maintain the square shape of the excavated volume. Oa material was sieved onto a tarp through a large $\left(\sim 0.25 \mathrm{~m}^{2}\right) 6$ $\mathrm{mm}$ stainless steel sieve in the field. Roots and woody fragments not passing the sieve were collected separately. Roots extending from the bottom and sides of the pit were clipped and added to the root sample. All removed O-horizon material was weighed in the field and brought back to the lab. Depth was measured again on a 25-point grid at the top of the mineral soil.

In 2003, representative subsamples of sieved soil from each depth increment were taken with a 
trowel, which may undersample roots long enough to tip off the trowel. In 2004, we used salad tongs, which would over sample long roots, except that roots protruding from the tongs were clipped with scissors (Park et al., 2007).

At six sites sampled in 2003, O horizons were also sampled using $10-\mathrm{cm}$ square pin-blocks (10 blocks composited by transect; five 50-m transects per site), for comparison with previous forest floor measurements at these sites (Federer, 1984; Yanai et al., 1999). These measurements allow a comparison of soil pits, excavated downward, with the pin-block method in which blocks are inverted and mineral soil removed from the bottom.

\section{Mineral horizon excavation}

Mineral soil horizons were excavated by depth in increments that varied by sampling year (Yanai et al. 2006; Park et al. 2007). In 2003, we sampled from 0$10 \mathrm{~cm}$ (from the top of the mineral soil), $10-20 \mathrm{~cm}$, 20-30 cm, and from $30 \mathrm{~cm}$ to the top of the $C$ horizon, while in 2004 we sampled from 0-10 cm, 10$30 \mathrm{~cm}, 30-50 \mathrm{~cm}$, and from $50 \mathrm{~cm}$ to the top of the $C$ horizon. The $\mathrm{C}$ horizon was sampled to $50 \mathrm{~cm}$ (as two layers, designated $\mathrm{C}_{0-25 \mathrm{~cm}}$ and $\mathrm{C}_{25-50 \mathrm{~cm}}$ ) in one pit per site, and in 2004 to $25 \mathrm{~cm}$ in the other two pits. In pits where $C$ horizons were not quantitatively sampled, a $\sim 10 \mathrm{~cm}$ deep core was taken at the top of the $\mathrm{C}$ horizon.

Shovels and trowels were used to loosen and remove the soil from each layer. As digging proceeded, depth was checked often to avoid digging too far, and the width of the pit was verified with a $70.7 \mathrm{~cm}$ length of wood. Excavated material was sieved through a $12-\mathrm{mm}$ stainless steel mesh in the field; roots and rocks not passing the sieve were weighed and subsampled.

Rocks that protruded from the pit walls and were $<10 \mathrm{~cm}$ on any exposed side were removed if possible. Rocks that were judged to be at least half in the pit were included in the rock mass; others were discarded without weighing. The in-pit mass of larger protruding rocks was estimated by reweighing rocks approximately equal in volume to the part of the rock protruding into the pit.

After removing each layer, depth measurements were taken on the grid. Measurements that fell on rocks were noted. The sieved soil was thoroughly mixed and weighed in buckets. Samples were taken from the last shovelful filling each bucket before it was weighed, accumulating a composite subsample of $\sim 2-4 \mathrm{~kg}$ for soil analysis and $\sim 100 \mathrm{~g}$ for root picking, by trowel or tongs, as described above (Park et al. 2007).

\section{Laboratory Methods}

\section{Soils}

Roots and soil subsamples to be picked for fine roots were refrigerated until they were processed (see Yanai et al., 2006; Park et al., 2007). Other samples were air-dried on brown kraft paper on wire racks, and covered with paper to prevent contamination by dust. Air-dried mineral soil samples were sieved to 2 $\mathrm{mm}$, and the $<2 \mathrm{~mm}$ fraction weighed. A subsample of the $<2 \mathrm{~mm}$ mineral soil fraction was oven-dried at 105 ㄷ․ Air-dried samples of the Oie were milled to 2 $\mathrm{mm}$, and all O-horizon subsamples were oven-dried at $60^{\circ} \mathrm{C}$. Subsamples were split with a rifflebox; some of each sample was archived at the Hubbard Brook Experimental Forest.

The dry mass of $<2 \mathrm{~mm}$ soil in each layer was calculated using the moisture content, mass, and coarse fraction of the sieved material weighed in the field. The thickness of the depth increment was calculated, excluding points that landed on rocks. Coarse fraction volume by layer was estimated including the volume of rocks protruding from the bottom of each layer (assuming each rock occupies the entire $200 \mathrm{~cm}^{2}$ grid cell it represents at the measured height) and the mass of rocks removed from each layer (including the 2-12 $\mathrm{mm}$ fraction) divided by a standard rock density of $2.65 \mathrm{~g} \mathrm{~cm}^{-3}$ (Telford et al., 1990). Bulk density was calculated by dividing the soil mass of the layer by the non-rock volume of each layer.

Subsamples (5-15 g) for $\mathrm{C}$ and $\mathrm{N}$ analysis were pulverized in a Spex mixer mill. Total $\mathrm{C}$ and $\mathrm{N}$ concentrations were measured on a CE instruments Model NC2100 elemental analyzer. The mass of sample analyzed ranged from 8-25 mg, depending on organic matter concentration; $10 \%$ of samples were run in triplicate. The coefficient of variation (CV) of $\mathrm{C}$ and $\mathrm{N}$ concentration data for samples run in triplicate was generally $<5 \%$ but occasionally approached $10 \%$. For C-horizon samples, where N concentrations were near the detection limit, CV's were sometimes considerably greater. All $\mathrm{C}$ was assumed to be organic, due to the granitic parent material and low soil $\mathrm{pH}$. 


\section{Roots}

Subsamples of roots from the $\mathrm{Oa}$ and mineral horizons (to a depth of $50 \mathrm{~cm}$ ) from the 18 pits excavated in 2004 were washed, dried at $60 \circ \mathrm{C}$, pulverized, and analyzed for $\mathrm{C}$ and $\mathrm{N}$ content on a Vario EL elemental analyzer. Three diameter classes ( $<1 \mathrm{~mm}, 1-5 \mathrm{~mm}$, and 5-10 mm) were analyzed.

\section{O-horizon coarse organic matter}

Among the $\mathrm{C}$ and $\mathrm{N}$ pools we analyzed in addition to soil were woody fragments from the forest floor that would not pass a $6 \mathrm{~mm}$ sieve. In 2003, the Oie samples from all 24 pits were forced through a $6-\mathrm{mm}$ sieve. Coarse (>6 mm) organic fragments from the Oie samples were analyzed for $C$ and N. At each of the 8 sites, we also selected one Oa sample from which to analyze organic material that did not pass the $6 \mathrm{~mm}$ sieve.

\section{Mineral horizon coarse fraction}

To estimate the importance of soil adhering to rocks, subsamples of rocks in the $2-12 \mathrm{~mm}$ and $12-80 \mathrm{~mm}$ size classes were reserved from excavated mineral layers, including the $\mathrm{C}$ horizon. In two pits ( $\mathrm{H} 1-2$ and H4-3) these samples were hand-washed to collect soil material adhering to them. These soil samples were oven-dried, weighed, and pulverized for $\mathrm{C}$ and $\mathrm{N}$ analysis. A paired t-test was used to test the hypothesis that these fines had the same $\mathrm{C}$ and $\mathrm{N}$ concentrations as the soil samples collected from the same depth increment. To estimate the $\mathrm{C}$ and $\mathrm{N}$ inside the rocks, rock subsamples from all layers in two other pits (C4-1 and C8-2) were washed, crushed, and pulverized for analysis. To identify geologic $\mathrm{C}$ and $\mathrm{N}$ from sources such as carbonate minerals and $\mathrm{NH}_{4}{ }^{+}$in silicate minerals (Holloway and Dahlgren, 2002), a subsample of $12-80 \mathrm{~mm}$ rocks from the deepest layer in each of the two pits was heated to 450 으 in a muffle furnace for 8 hours to remove organic $\mathrm{C}$ and $\mathrm{N}$ before analysis. To broaden this analysis, representative bedrock samples of two local lithologies, Conway granite (Redstone Quarry, Conway) and Mt. Osceola granite (Bartlett Experimental Forest) were analyzed in the same way.

We estimated the $\mathrm{C}$ and $\mathrm{N}$ content of rocks by applying concentrations measured in each layer's 2$12 \mathrm{~mm}$ rock fraction to the mass of that fraction, and concentrations in the $12-80 \mathrm{~mm}$ rock fraction to all $>12 \mathrm{~mm}$ rock mass in each layer.

\section{Literature review}

We reviewed published studies that used quantitative pits to directly measure total soil and coarse fraction mass (Appendix). We searched Google Scholar and ISI Web of Science for the terms "quantitative", "volumetric" and "soil pit", and also examined studies referencing Hamburg (1984a), Huntington et al. (1988), Johnson et al. (1991a,b) or Johnson (1995) for methods. We excluded studies in which pit volume was measured by displacement or pits that were not sampled quantitatively to depths $>10 \mathrm{~cm}$ into the mineral soil.

Where possible, we reported the mean and coefficient of variation (CV) of soil mass and soil C (O-horizon, mineral soil, and total), and root mass (total only) for each study site. For each site, we calculated the detectable change (based on an unpaired t-test, $\alpha=0.05$, power $=0.75$ ) if resampled with the same number of pits, as well as the likelihood of detecting a 20\% change with $95 \%$ confidence if resampled with the same number of pits. These calculations were conducted with $\mathrm{R} 2.10$ software using the function pwr.t.test (Champley, 2009).

\section{Results}

\section{Accounting of Belowground $\mathrm{C}$ and $\mathrm{N}$ stocks}

Soil mass, coarse fraction, and bulk density

O-horizon depth averaged $6.3 \pm 3.1$ (all results are reported as mean \pm SD) $\mathrm{cm}$ across sites, and Ohorizon mass averaged $10.9 \pm 7.0 \mathrm{~kg} \mathrm{~m}^{-2}$. Both depth and mass were notably high at BW, a former woodlot dominated by hemlock and northern hardwoods, and $\mathrm{H} 6$, a young stand in a toe-slope position with areas of poor drainage (Table 1). The CV of mean Ohorizon mass across the 14 sites (64\%) was generally greater than the CV of replicate pits within sites, which ranged from $19 \%$ to $77 \%$ (Table 1 ).

Mineral soil mass (to the top of the $C$ horizon) averaged $400 \pm 130 \mathrm{~kg} \mathrm{~m}^{-2}$, and correlated strongly with depth to the $C$ horizon $\left(R^{2}=0.73\right)$. Bulk density increased significantly with depth (Figure 2), averaging $0.65 \pm 0.12 \mathrm{~g} \mathrm{~cm}^{-3}$ in the $0-10 \mathrm{~cm}$ layer, $0.99 \pm 0.28 \mathrm{~g} \mathrm{~cm}^{-3}$ in the $50 \mathrm{~cm}-\mathrm{C}$ layer, and $1.50 \pm$ 0.26 in the $C_{25-50 \mathrm{~cm}}$ layer. At one of our sites (M5), we were unable to sample C-horizon material because soil rested on bedrock in all three pits. In another site $(\mathrm{H} 4)$, the pit designated for C-horizon sampling had approximately $10 \mathrm{~cm}$ of $\mathrm{C}$ horizon over 
bedrock. In 37 of 42 pits (88\%) we were able to sample the $\mathrm{C}$ horizon as planned.

Coarse fraction volume showed a significant but poorly predictive relationship with depth (Figure 2), and was slightly greater in C horizons ( $31 \pm 18 \%$ ) than other mineral horizons ( $24 \pm 15 \%$ ); (unpaired ttest, $p=0.05)$. Coarse fragments ranged from gravel to large boulders. Soil particles adhering to coarse fragments accounted for an additional 3-8\% of soil mass in the two pits where they were processed.

\section{$C$ and $N$ in commonly sampled pools}

The Oie averaged $45.8 \pm 4.3 \% \mathrm{C}$ and $1.69 \pm 0.33 \% \mathrm{~N}$, totaling $933 \pm 365 \mathrm{~g} \mathrm{C} \mathrm{m}-2$ and $35 \pm 16 \mathrm{~g} \mathrm{~N} \mathrm{~m}^{-2}$ (Table 2). The $<6 \mathrm{~mm}$ Oa horizon averaged $29.2 \pm 8.4 \% \mathrm{C}$ and $1.25 \pm 0.37 \% \mathrm{~N}$, representing a stock of $2560 \pm$ $2270 \mathrm{~g} \mathrm{C} \mathrm{m}^{-2}$ and $106 \pm 83 \mathrm{~g} \mathrm{~N} \mathrm{~m}^{-2}$. Nine of 42 sampled Oa horizons had $<20 \% \mathrm{C}$, indicating that some of the material we included as Oa based on field properties did not meet the definition for this horizon (20\% organic C). Because of the difficulties of distinguishing $\mathrm{Oa}$ from thin A horizons in the field (Yanai et al., 2000), soil studies in the region typically lump the $\mathrm{O}$ and $\mathrm{A}$ horizons together as the "forest floor", and mark the top of the mineral soil where the Oa or A transitions to $\mathrm{E}$ or $\mathrm{B}$, which is easier to identify consistently (Federer, 1982; Yanai et al., 1999, 2000). At the six sites where the forest floor was sampled both by soil pits and forest floor pinblocks ( 5 lines of 10 composited samples per site) in 2003, pits estimated $9 \%$ greater $C$ content and $2 \%$ greater $\mathrm{N}$. Within stands, on average, the CV was greater for 3 pits (52\%) than for 5 composite lines of blocks (30\%), even though the pits sample three times more surface area, confirming that there is significant variation at scales larger than the soil pit.

Mineral soil $\mathrm{C}$ and $\mathrm{N}$ concentrations decreased rapidly and systematically with depth; log-log regressions were highly significant (Figure 3). Nevertheless, mineral soil contained much more $C$ and $\mathrm{N}$ than the forest floor layers, because of its much greater mass. The $\mathrm{E}+\mathrm{B}$ horizons averaged $8990 \pm 2230 \mathrm{~g} \mathrm{C} \mathrm{m}^{-2}$ and $420 \pm 110 \mathrm{~g} \mathrm{~N} \mathrm{~m}^{-2}$ (Table 3).

\section{$C$ and $N$ in the $C$ horizon}

The $\mathrm{C}_{0-25 \mathrm{~cm}}$ horizon contained $1070 \pm 910 \mathrm{~g} \mathrm{C} \mathrm{m}^{-2}$ and $48 \pm 36 \mathrm{~g} \mathrm{~N} \mathrm{~m}^{-2}$ where present, adding $6-37 \%$ to the mineral soil totals, depending on the site. Where present and sampled, the $\mathrm{C}_{25-50 \mathrm{~cm}}$ horizon contained $650 \pm 720 \mathrm{~g} \mathrm{C} \mathrm{m}^{-2}$ and $27 \pm 29 \mathrm{~g} \mathrm{~N} \mathrm{~m}^{-2}$, adding 2-20\% to the mineral soil totals. Across pits with both $\mathrm{C}_{0}$ $25 \mathrm{~cm}$ and $C_{25-50 \mathrm{~cm}}$ layers sampled, the
$\mathrm{C}_{25-50 \mathrm{~cm}}$ layer had significantly lower $\mathrm{C}$ concentrations (Table 3; paired t-test, $p<0.01$ ). Carbon concentrations in the upper $C$ horizon were higher where soils were shallow (linear regression; $p=0.08$ for pits with $\mathrm{C}_{0-25 \mathrm{~cm}}$ samples and 0.41 for pits with cores at the top of the $\mathrm{C}$ horizon).

\section{$C$ and $N$ in coarse organic material}

Belowground material that doesn't pass a sieve is often excluded from ecosystem budgets. The $>6 \mathrm{~mm}$ material from the Oie (mostly twigs and wood fragments) ranged in mass from 108 to $1230 \mathrm{~g} \mathrm{~m}^{-2}$, averaging $437 \mathrm{~g} \mathrm{~m}^{-2}$ across the 24 pits excavated in 2003 , or $20 \%$ of the mean total sample mass. Concentrations of $\mathrm{N}$ were much lower than in the material that passed the sieve $(0.73 \%$ vs $1.87 \%)$, but C concentrations were similar ( $51 \%$ vs $45 \%$ ). The amount of coarse material averaged $223 \mathrm{~g} \mathrm{C} \mathrm{m}^{-2}$ and $3.2 \mathrm{~g} \mathrm{~N} \mathrm{~m}^{-2}$, accounting for 22 and $9 \%$ of the Oie totals. To simplify lab processing, we included coarse organic material in Oie samples collected in 2004 , by milling the entire sample before analysis.

In the Oa horizon, the $>6 \mathrm{~mm}$ material was mostly wood and bark. The mass of this material ranged from $8-322 \mathrm{~g} \mathrm{~m}^{-2}$, averaging $123 \mathrm{~g} \mathrm{~m}^{-2}$, or $1.5 \%$ of the mean total Oa mass from the 8 pits in which it was analyzed (one per site in 2003). C concentrations were greater in the $>6 \mathrm{~mm}$ material than in the material that passed the sieve (50\% vs. $33 \%$ on average), but as in the Oie, $\mathrm{N}$ concentrations were smaller ( $0.76 \%$ vs. $1.41 \%)$. C content averaged $61 \mathrm{~g}$ $\mathrm{m}-2$, and $\mathrm{N}$ content only $0.7 \mathrm{~g} \mathrm{~m}^{-2}$. Overall, the coarse organic pool accounted for $3.3 \%$ of the $\mathrm{Oa}$ horizon $\mathrm{C}$ stock and $1.1 \%$ of the $\mathrm{N}$ stock.

\section{$C$ and $N$ in and on coarse mineral fragments}

The $\mathrm{C}$ and $\mathrm{N}$ content of soil washed from coarse mineral fragments in two pits amounted to $2-10 \%$ ( mean $=4.5 \%$ ) of sieved soil $\mathrm{C}$ content of each layer, and $2-9 \%$ (mean $=4.8 \%$ ) of the $\mathrm{N}$ content. The fraction of total layer $\mathrm{C}$ content found in soil adhering to rocks showed a marginally significant correlation with coarse fraction volume $\left(R^{2}=0.40 ; p\right.$ $=0.05$ ). Because these soil samples were not systematically different in $\mathrm{C}$ and $\mathrm{N}$ concentration from the corresponding bulk soil, additional $\mathrm{C}$ and $\mathrm{N}$ contents are similar to the mass proportions reported above. At the scale of a whole pit, this additional soil pool contained 323-1060 $\mathrm{g} \mathrm{C} \mathrm{m}^{-2}$ and 17-49 $\mathrm{g} \mathrm{N} \mathrm{m}^{-2}$, the inclusion of which would add 3\% on average to total (O-horizon plus mineral soil) stocks (Table 3). 
The rocks themselves had concentrations of 0.02$0.06 \% \mathrm{C}$ and $0.001-0.023 \% \mathrm{~N}$. Concentrations were lower in the $12-50 \mathrm{~mm}$ size fraction than in the 2-12 $\mathrm{mm}$ fraction, and decreased systematically with depth, consistent with a lesser weathered surface. We estimate that rocks contain an additional 410$860 \mathrm{~g} \mathrm{C} \mathrm{m}^{-2}$ and 22-34 $\mathrm{g} \mathrm{N} \mathrm{m}^{-2}$, increasing the total belowground $\mathrm{C}$ content of each pit by 6 to $8 \%$. Unweathered bedrock and C-horizon rock material treated in a muffle furnace to remove organic matter were near the detection limit for $\mathrm{C}$ and $\mathrm{N}$ (70150 ppm C and 5-10 ppm N), indicating relatively little geologic contribution to these totals.

\section{$C$ and $N$ in Roots}

Carbon concentrations of roots in 18 pits varied little with depth or size class; for simplicity we used the mean value $(48 \%)$ for all roots. Nitrogen concentrations, however, varied substantially with diameter. In the Oa horizon, roots $<1 \mathrm{~mm}$ dominated the total mass and averaged $1.2 \% \mathrm{~N}$. Mineral horizon roots $<1 \mathrm{~mm}$ averaged $0.8 \% \mathrm{~N}$, and roots $>1 \mathrm{~mm}$ averaged $0.5 \% \mathrm{~N}$. We used these means to calculate root $\mathrm{C}$ and $\mathrm{N}$ content across all pits.

In the $\mathrm{O}$ horizon, root $\mathrm{C}$ ranged from $113-1250 \mathrm{~g} \mathrm{C} \mathrm{m}$ ${ }^{2}$ (mean of 399 , or $12 \%$ of total) and root $\mathrm{N}$ ranged from 1.6-15.1 $\mathrm{g} \mathrm{N} \mathrm{m}^{-2}$ (mean 5.4, 4\% of total; Table 2 ). The wide ranges may reflect differences in methods as well as natural variation across years and stands. Sieved Oie subsamples picked for roots in 2003 yielded only about $25 \%$ as much root mass as the intact Oie subsamples picked in 2004 (Park et al. 2007).

Roots in the mineral soil ranged in $\mathrm{C}$ content from 3$13 \%$ (by site) of the corresponding mineral soil $<2$ $\mathrm{mm}$ carbon stock, averaging $10 \%$. For nitrogen, the range was $0.9 \%$ to $4.4 \%$, averaging $2.7 \%$ (Table 3 ). Roots in the $\mathrm{C}$ horizon amounted to $5 \%$ of the Chorizon $\mathrm{C}$ stock and $1.4 \%$ of the $\mathrm{N}$ stock, on average.

\section{Power analysis for this and other studies}

The CV of total soil mass across the three pits in each site varied widely, from $20 \%$ to $72 \%$, averaging $37 \%$ (Table 4). The minimum detectable change in Ohorizon mass (with $95 \%$ confidence, and accepting a type II error rate of $25 \%$ ), if three pits were to be measured at a future date with the same variance, ranged from $55 \%$ to $221 \%$, averaging $140 \%$. Clearly, such sampling schemes are not likely to detect modest stock changes. If only the forest floor is of interest, block sampling methods are much more efficient, because many small samples can be taken for the same effort as a few large soil pits. Thus many forest floor studies are capable of detecting changes as small as 20-30\% (Yanai et al., 2003b). Across all studies on quantitative pits in the literature, the lowest detectable change for the forest floor was reported by Wibralske et al. (2004), with a $23 \%$ detectable change with $n=40$ pits. At Hubbard Brook W5, with 60 pits in each year sampled, the mean detectable O-horizon change was about $44 \%$.

The CV of total soil C within a site ranged from 3\% (site C2) to 63\% (Johnson et al. 2011), averaging 24\% across all the studies we surveyed (Table 5). In our study, with 3 pits per site per sampling date, the minimum detectable change (accepting a type II error rate of $25 \%$ ) ranged from $9 \%$ to $125 \%$, averaging 57\%. At Hubbard Brook, with 60 pits per sampling date, the detectable change was about $20 \%$.

For total root mass, the CV among pits within a site in our data set ranged from $11 \%$ (site M6) to $90 \%$, averaging 46\%. Fernandez et al. (1993) and Rau et al. (2009) had CVs in this range. At Hubbard Brook, the CV was considerably greater (153\%), perhaps due to the range in soil depth and vegetation type in the large site sampled. In our study, with 3 pits per sampling date, the minimum detectable change ranged from $33 \%$ to $259 \%$. Even with 60 pits, the Hubbard Brook data (Fahey et al., 1988) could only detect changes of $75 \%$ or more.

\section{Discussion}

\section{Distribution of belowground $\mathrm{C}$ and $\mathrm{N}$}

Despite decreasing concentrations of $\mathrm{C}$ and $\mathrm{N}$ with depth (Figure 3 ), the mass of the $C$ horizon makes it an unexpectedly large stock of $\mathrm{C}$ and $\mathrm{N}$ (Table 3 ): including the top $50 \mathrm{~cm}$ of the $\mathrm{C}$ horizon increased the measured soil $\mathrm{C}$ pool by as much as $49 \%$. Most of our sites had $\mathrm{C}$ horizons deeper than $50 \mathrm{~cm}$, but our quantitative sampling ended at this depth. Whether the $\mathrm{C}$ horizon should be considered depends on the study system, the specific questions, and the stability of C-horizon organic matter. The $\mathrm{C}$ horizon may have some importance to ecosystem budgets, as its top $25 \mathrm{~cm}$ contained $5 \%$ of all fine roots and the next $25 \mathrm{~cm}$ contained 2\% (Park et al. 2007); similar C-horizon root abundances have been observed elsewhere in the northeastern US (e.g. Donahue, 1940). The importance of these pools is 
unclear, as the turnover and activity of C-horizon roots is not well known.

Another pool typically not reported is the material not passing a soil sieve. In the $\mathrm{O}$ horizon, we found that $8 \%$ of $\mathrm{C}$ and $3 \%$ of $\mathrm{N}$ was in wood and bark fragments $>6 \mathrm{~mm}$. This material is also not usually measured in surveys of aboveground woody debris. This material can be included in the Oie sample for $C$ and $\mathrm{N}$ analysis because it goes through a Wiley mill; in the $\mathrm{Oa}$, it is processed separately, because the mineral content of the Oa precludes such milling. Coarse organic fragments appear to be highly variable in importance among ecosystems; they have been reported to account for $5-12 \%$ of $C$ and $1-5 \%$ of $\mathrm{N}$ in the A horizon in coniferous stands in California (Black and Harden, 1995) and 34\% of O-horizon mass in a conifer forest in Maine (Fernandez et al., 1993). Differences among sites may reflect differences in disturbance history as well as current input and decomposition rates for this pool.

Commonly, root fragments that pass a $2 \mathrm{~mm}$ sieve are included in analysis of the soil fraction. If root mass is independently estimated in an ecosystem budget, these roots are counted twice. On the other hand, if roots are not estimated by other means, the roots that do not pass a soil sieve are not counted at all. In our sites, roots amounted to 5-18\% (mean $12 \%$ ) of total soil C and 1-5\% (mean $3 \%$ ) of total soil N. Kulmatiski et al. (2003) similarly found that roots amounted to $10 \%$ of $\mathrm{C}$ and $2 \%$ of $\mathrm{N}$ of the $0-15 \mathrm{~cm}$ soil pools. Live and dead fine roots represent a dynamic and potentially very responsive $C$ stock, and may be particularly important to monitor for change in manipulated and disturbed ecosystems.

Soil particles adhering to rocks accounted for a surprisingly large fraction of $\mathrm{C}$ in the two pits in which they were measured (3.5-5.6\% of the mineral soil and $\mathrm{C}$ horizon combined), and a similar fraction of nitrogen (3.9-5.7\%) (Table 3). The fraction of soil adhering to rocks likely varies widely with the size distribution of coarse fragments, soil structure and texture, and soil moisture when excavated; the amount of soil not weighed for this reason may be worth determining in other systems and sampling methods. However, our findings suggest that it is not necessary to analyze this soil for $\mathrm{C}$ and $\mathrm{N}$ concentrations, since they did not differ systematically from bulk soil. Harrison et al. (2003) found that soil adhering to the $>2 \mathrm{~mm}$ fraction accounted for $3.5 \%$ of total soil $\mathrm{C}$ in a loamy sand from Washington, but $63 \%$ in a nearby very gravelly sandy loam. Whitney and Zabowski (2004) documented $0-35 \%$ of total soil $\mathrm{N}$ associated with the coarse fraction; this study did not distinguish ecosystem-derived organic matter from organic content in sedimentary rocks, or geologic $\mathrm{N}$ in crystalline minerals (Holloway and Dahlgren 2002). In the granitic soils of the White Mountain region, geologic $\mathrm{N}$ appears unimportant. However, the small rocks we washed still had up to $0.6 \% \mathrm{C}$ and $0.02 \% \mathrm{~N}$ from organic sources. Applying these concentrations to the mass of all rocks in the pits gave estimates of $400-860 \mathrm{~g} \mathrm{C} \mathrm{m}^{-2}$ in ecosystemderived organic matter (Table 3); this is probably an overestimate, as larger rocks likely have lower concentrations of $\mathrm{C}$ and $\mathrm{N}$ far from the weathering front.

The size and variability of these largely unmeasured components of the belowground $\mathrm{C}$ and $\mathrm{N}$ pool shows their possible importance to belowground monitoring. If comparing ecosystems or change over time, it is important to be consistent in the treatment of roots, soil particles attached to coarse fragments, coarse material in the forest floor, and C horizon stocks.

\section{Site differences in belowground $\mathrm{C}$ and $\mathrm{N}$ stocks}

Twelve of the sites we sampled were selected in part to represent a chronosequence of forest regeneration following commercial cutting. Unlike other such studies (Diochon et al., 2009; Neurath, 2011), we did not observe systematic differences in soil $\mathrm{C}$ content with time since harvest across the 12 sites with known harvest dates (Figure 4). Mineral soil $\mathrm{C}$ content was below the mean in the three youngest stands sampled (14-19 years), but it is not clear that this constitutes evidence of $C$ loss due to harvesting. We regard the chronosequence approach as problematic in assessing changes in total $C$ following disturbance, due to high preexisting variability among sites and differences in harvest intensity and technique among stands (Yanai et al., 2000, 2003a). Repeating quantitative soil sampling across a variety of sites could help to improve estimates of soil $\mathrm{C}$ fluxes following harvest disturbance.

\section{Reviewing the quantitative pit method}

The primary advantage of the quantitative soil pit method is the accurate, direct measurement of soil mass, obviating the need to measure bulk density and estimate coarse fraction, as is necessary with profile-sampling approaches, and reducing the 
potentially large sampling bias associated with corebased methods, which avoid rocks. In the 40+ studies that have employed quantitative pits (Appendix), a variety of modified methods have emerged. Many studies (e.g. Kulmatiski et al., 2003; Hooker and Compton, 2003; Wibiralske et al., 2004) used pits only $50 \mathrm{~cm}$ square $\left(0.25 \mathrm{~m}^{2}\right)$, which expedites the process, but limits the total depth that can be excavated cleanly; our $0.5 \mathrm{~m}^{2}$ pits allow a person to work from inside the pit. Richter et al. (1989) excavated small pits, only $0.05 \mathrm{~m}^{2}$, to a depth of $40 \mathrm{~cm}$. Using smaller pits may allow for additional replication, particularly where only shallow horizons are of concern. Canary et al. (2000) did not remove large rocks, and instead continued digging only the portions of the pit where a large rock had not yet been encountered. Johnson et al., (1997, 2008, 2011) did not measure depth on a grid, but calculated the excavated volume from the soil mass and bulk density measured in pit-wall cores (this method may be preferable if bulk density is a parameter of interest, e.g. in studying soil compaction as a disturbance effect). The critical similarity among these methods is the direct measurement of soil mass to a known depth in a unit area. This is important in rocky soils because estimating soil volume from rock volume is prone to error, especially when rock volume is high. The error associated with using mapped soil-unit estimates of coarse fraction rather than measuring the coarse fraction directly may be as large as 55\% (Fernandez et al. 1993). The other advantage of pit methods is the large volume of soil sampled, which avoids the danger of taking concentration and bulk density samples that are inconsistent.

Because samples are collected while excavating downward, quantitative pit methods typically sample mineral horizons in depth increments, rather than by genetic horizon, except where horizon transitions are reliably sharp and predictable in appearance. Depth-based sampling may be advantageous when monitoring responses to disturbance that can change or mix soil horizons (e.g. harvesting; Martin, 1988). Sampling to a deep, recognizable transition (e.g. top of the C horizon), ensures that mineral soil organic matter is not systematically over- or under-estimated by a repeated sampling strategy in a changing soil profile.

\section{Quantitative Pits vs. coring}

Other studies have compared the effort required to sample using quantitative soil pits and soil cores for precisely measuring soil $\mathrm{C}$ and $\mathrm{N}$ stocks. For example, at 18 plots in Connecticut, Inceptisols and Entisols sampled to $15 \mathrm{~cm}$ depth differed by less than $<12 \%$ in $\mathrm{C}$ and $\mathrm{N}$ concentrations between pit and core samples (Kulmatiski et al. 2003), though bulk density and coarse fraction were both significantly greater in pits than in cores. In the Pacific Northwest, cores underestimated soil C relative to pits by up to $70 \%$ in soils where the coarse fraction was an important $\mathrm{C}$ stock (Harrison et al., 2003).

In four of the sites where we excavated soil pits in 2004, both pits and cores were used to measure root biomass (Park et al. 2007). Fine $(<2 \mathrm{~mm}$ ) root biomass in the $O$ horizon and top $10 \mathrm{~cm}$ of the mineral soil was $27 \%$ greater in cores than pits. These cores were taken with long PVC cores, and divided into depth increments after removal; soil compaction in the cores contributed about $10 \%$ to the systematic difference between cores and pits, with the rest attributed to obstruction by rocks and coarse roots. Motorized rotary coring, because depth increments are extracted sequentially, avoids bias from compaction and suffers fewer obstructions by rocks; in a desert system in NV, there was little systematic difference in root biomass estimates from $0.25 \mathrm{~m}^{2}$ quantitative pits and 7.6-cm diameter powered rotary cores (Rau et al. 2009). Coarse roots (those $>2 \mathrm{~mm}$ diameter) are sampled poorly by small-diameter cores (Park et al., 2007), which may explain the wide margin by which pit measurements of roots sometimes exceed core measurements (e.g. by $220 \%$ in the case of Kulmatiski et al. 2003). Even quantitative pits are not able to sample the coarsest roots, as sampling locations are rejected if they have large root crowns.

Cores taken with a powered rotary are attractive for several reasons. Unlike push-cores, they can sample through small rocks and large roots, access soils to a depth of 1 m (Rau et al., 2009, 2011; Levine et al., 2012), and require far less effort per sample than quantitative pits. Like quantitative pits, they can sample by depth, but not by horizon, if the core is not removed intact. However, pits, unlike power cores, can stop at horizon transitions that are predictable in appearance (e.g. bottom of the $B$ horizon). The grinding of rock and soil particles make power core samples unsuitable for some analyses (e.g. exchangeable cations, texture), and some contamination among horizons can occur when removing and re-inserting the corer (Levine et al. 2012). These differences may make power-core 
samples inappropriate for comparison with quantitative-pit or pit-wall profile samples. Where the objective is to quantify total $\mathrm{C}$ and $\mathrm{N}$ with depth, power cores occupy a middle ground between the lower bias of quantitative pits and the increased replication possible with coring (Rau et al., 2011). However, any method that cannot sample through rocks (including power cores on some soils; Levine et al. 2012) has an inherent sampling bias if there is soil unsampled below the rock.

\section{Considerations for repeated sampling}

Quantitative pits are labor-intensive to excavate. Our soil pits each took 3-8 person-days to excavate and process in the field, with the C-horizon sampling taking a disproportionately large fraction of the total effort. Kulmatiski et al. (2003) estimated that a 0.25 $\mathrm{m}^{2}$ pit took 3.5 person-hours to excavate to $15 \mathrm{~cm}$, or 8 person-hours to $60 \mathrm{~cm}$. Our experience with 0.5 $\mathrm{m}^{2}$ pits is that two people can reliably excavate a pit to at least $30 \mathrm{~cm}$ and field-process the samples in a day. Below $50 \mathrm{~cm}$, excavation slows considerably, especially in rocky or compact soils.

For repeated sampling, the disturbance associated with pit excavation must be considered. Within a radius of 1-3 meters around each pit, there is substantial disturbance due to trampling, the piling of rocks and soil, occasional spillage, and the cutting of shrubs and small trees. Where the organic horizon is thick, compaction is often obvious after excavation. We sieved and piled soils on $\sim 4 \mathrm{~m}^{2} 6$-mil polyethylene sheets, and in level and reasonably accessible sites it may be feasible to minimize soil compaction by walking on wide planks. Careful planning prior to digging (locating sieved soil and rock piles on areas with little microtopography, or in previously disturbed areas) can also help. Because of the disturbance associated with excavation, we recommend locating paired re-measurement pits at least $3 \mathrm{~m}$ distant from previous sample points. Ideally, the locations of future pits would be marked in advance and the locations protected from disturbance (e.g. Huntington et al., 1988). It is not clear whether pairing pits improves statistical power; at Hubbard Brook W5, mineral soil mass was poorly predicted in 1986, 1991, and 1998 by the soil mass of the paired pre-treatment pit 3-6 $\mathrm{m}$ away $\left(\mathrm{R}^{2}=\right.$ 0.03-0.16).

Choosing an approach to soil sampling depends on the questions being asked and the resources available. Quantitative soil pits accurately quantify soil mass and provide samples representative of relatively large volumes of soil. Many $\mathrm{C}$ budgeting applications demand both precision, for statistically significant change detection, as well as accuracy, for scaling up changes on a per-area basis. Where there is large variance in horizon thickness or other soil properties at scales larger than the pit area, pits likely yield less precise estimates of nutrient stocks than an equivalent (or smaller) effort devoted to coring. Future sampling efforts should be designed with consideration of the relative importance of accuracy vs. precision, shallow vs. deep soils, and cumulative site disturbance.

\section{Acknowledgements}

Soils were excavated and analyzed with the field and laboratory assistance of M. Acker, R. Averbeck, C. Blodgett, J. Boley, H. Clark, A. Coria, M. Deringer, C. Fuss, M. Germain, A. Just, P. Lilly, S. Miftari, E. O'Donnell, N. Ross, N. Shapiro, D. Tucker, and B. Weeks, among others. Bartlett Experimental Forest is operated by the USDA Forest Service Northern Research Station, Newtown Square, PA. This work was funded in part by NSF grants DEB 0235650 and DEB 9810221, and is a contribution to the Hubbard Brook Ecosystem Study.

\section{References}

Bailey, S.W., S.B. Horsley, and R.P. Long. 2005. Thirty Years of Change in Forest Soils of the Allegheny Plateau, Pennsylvania. Soil Science Society of America Journal 69(3): 681.

Bethlahmy, N. 1952. A method for approximating the water content of soils. Transactions of the American Geophysical Union 33: 699-706.

Black, T., and J. Harden. 1995. Effect of timber harvest on soil carbon storage at Blodgett Experimental Forest, California. Canadian Journal of Forest Research 25(8): 1385-1396.

Boone, R.D., D.F. Grigal, P. Sollins, R.J. Ahrens, and D.E. Armstrong. 1999. Soil sampling, preparation, archiving, and quality control. p. 3-28. In Robertson, G.P., Coleman, D.C., Bledsoe, C.S., Sollins, P. (eds.), Standard Soil Methods for Long-term Ecological Research. Oxford University Press, New York.

Bélanger, N., and K.C.J. van Rees. 2008. Sampling forest soil. p. 15-24. In Carter, M.R., Gregorich, E.G. (eds.), Soil sampling and methods of analysis. 2nd ed. CRC Press, Boca Raton, FL. 
Canary, J.D., R.B. Harrison, J.E. Compton, and H.N. Chappell. 2000. Additional carbon sequestration following repeated urea fertilization of second-growth Douglas-fir stands in western Washington. Forest Ecology and Management 138(1-3): 225-232.

Champley, S. 2009. pwr: Basic functions for power analysis (R package, version 1.1.1).

Diochon, A.C., L. Kellman, and H. Beltrami. 2009. Looking deeper: An investigation of soil carbon losses following harvesting from a managed northeastern red spruce (Picea rubens Sarg.) forest chronosequence. Forest Ecology and Management 257(2): 413-420.

Donahue, R.L. 1940. Forest-site quality studies in the Adirondacks 1 . Tree growth as related to soil morphology.

Ellert, B.H., H.H. Janzen, A.J. VandenBygaart, and E. Bremer. 2008. Measuring change in soil organic carbon storage. p. 25-38. In Carter, M.R., Gregorich, E.G. (eds.), Soil sampling and methods of analysis. 2nd ed. CRC Press, Boca Raton, FL.

Fahey, T.J., J.W. Hughes, M. Pu, and M.A. Arthur. 1988. Root decomposition and nutrient flux following wholetree harvest of northern hardwood forest. Forest Science 34(3): 744-768.

Federer, C.A. 1982. Subjectivity in the separation of organic horizons of the forest floor. Soil Science Society of America Journal 46: 1090-1093.

Federer, C.A. 1984. Organic matter and nitrogen content of the forest floor in even-aged northern hardwoods. Canadian Journal of Forest Research 14(6): 763-767.

Fernandez, I.J., L.E. Rustad, and G.B. Lawrence. 1993. Estimating total soil mass, nutrient content, and trace metals in soils under a low elevation spruce-fir forest. Canadian Journal of Soil Science 73(3): 317-328.

Hamburg, S.P. 1984a. Effects of forest growth on soil nitrogen and organic matter pools following release from subsistence agriculture. p. 145-158. In Stone, E.L. (ed.), Forest Soils and Treatment Impacts. University of Tennessee, Knoxville, TN.

Hamburg, S.P. 1984b. Organic matter and nitrogen accumulation during 70 years of old-field succession in central New Hampshire.

Harrison, R.B., A.B. Adams, C. Licata, B. Flaming, G.L. Wagoner, P. Carpenter, and E.D. Vance. 2003. Quantifying Deep-Soil and Coarse-Soil Fractions: Avoiding Sampling Bias. Soil Science Society of America Journal 67: 1602-1606.

Harrison, R.B., P.W. Footen, and B.D. Strahm. 2011. Deep soil horizons: contribution and importance to soil carbon pools and in assessing whole-ecosystem response to management and global change. Forest Science 57(1): 67-76.
Holloway, J.M., and R.A. Dahlgren. 2002. Nitrogen in rock : Occurrences and biogeochemical implications. Global Biogeochemical Cycles 16(4): 1118.

Hooker, T.D., and J.E. Compton. 2003. Forest Ecosystem Carbon and Nitrogen Accumulation During the First Century After Agricultural Abandonment. Ecological Applications 13(2): 299-313.

Huntington, T.G., D.F. Ryan, and S.P. Hamburg. 1988. Estimating Soil Nitrogen and Carbon Pools in a Northern Hardwood Forest Ecosystem. Soil Science Society of America Journal 52: 1162-1167.

Johnson, C.E. 1995. Soil nitrogen status 8 years after whole-tree clear-cutting. Canadian Journal of Forest Research 25(8): 1346-1355.

Johnson, C.E., C.T. Driscoll, T.J. Fahey, T.G. Siccama, and J.W. Hughes. 1995. Carbon dynamics following clearcutting of a northern hardwood forest. p. 463-488. In McFee, W.W., Kelly, J.M. (eds.), Carbon forms and functions in forest soils. SSSA, Madison, WI.

Johnson, D.W., C.T. Hunsaker, D.W. Glass, B.M. Rau, and B.A. Roath. 2011. Carbon and nutrient contents in soils from the Kings River Experimental Watersheds, Sierra Nevada Mountains, California. Geoderma 160(3-4): 490-502.

Johnson, C.E., A.H. Johnson, T.G. Huntington, and T.G. Siccama. 1991a. Whole-Tree Clear-Cutting Effects on Soil Horizons and Organic-Matter Pools. Soil Science Society of America Journal 55(2): 497-502.

Johnson, C.E., A.H. Johnson, and T.G. Siccama. 1991b. Whole-tree clear-cutting effects on exchangeable cations and soil acidity. Soil Science Society of America Journal 55: 502-508.

Johnson, D.W., J.D. Murphy, R.F. Walker, W.W. Miller, D.W. Glass, and D.E.J. Todd. 2008. The combined effects of thinning and prescribed fire on carbon and nutrient budgets in a Jeffrey pine forest. Annals of Forest Science 65(6): 601-601.

Johnson, D.W., R.B. Susfalk, and R.A. Dahlgren. 1997. Nutrient fluxes in forests of the eastern Sierra Nevada mountains, United States of America. Global Biogeochemical Cycles 11(4): 673-681.

Kulmatiski, A., D.J. Vogt, T.G. Siccama, and K.H. Beard. 2003. Detecting nutrient pool changes in rocky forest soils. Soil Science Society of America Journal 67(4): 1282-1286.

Levine, C.R., R.D. Yanai, M.A. Vadeboncoeur, S.P. Hamburg, A.M. Melvin, C.L. Goodale, B.M. Rau, and D.W. Johnson. 2012. Assessing the suitability of using rotary coring for sampling in rocky soils. Soil Science Society of America Journal in press.

Lorenz, K., R. Lal, and M.J. Shipitalo. 2011. Stabilized soil organic carbon pools in subsoils under forest are 
potential sinks for atmospheric CO2. Forest Science 57(1): 19-25.

Lyford, W.H. 1964. Coarse fragments in the Gloucester soils of the Harvard Forest.

Martin, C.W. 1988. Soil disturbance by logging in New England--review and management recommendations. Northern Journal of Applied Forestry 5: 30-34.

Nave, L.E., E.D. Vance, C.W. Swanston, and P.S. Curtis. 2010. Harvest impacts on soil carbon storage in temperate forests. Forest Ecology and Management 259(5): 857-866.

Neurath, R.A. 2011. Carbon Loss in Mineral Soil Horizons: The Effects of 120 Years of Forest Harvesting in Northern New England.

Park, B.B., R.D. Yanai, M.A. Vadeboncoeur, and S.P. Hamburg. 2007. Estimating Root Biomass in Rocky Soils using Pits, Cores, and Allometric Equations. Soil Science Society of America Journal 71(1): 206-213.

Rau, B.M., D.W. Johnson, J.C. Chambers, R.R. Blank, and A. Lucchesi. 2009. Estimating Root Biomass and Distribution After Fire in a Great Basin Woodland Using Cores and Pits. Western North American Naturalist 69(4): 459-468.

Rau, B.M., A.M. Melvin, D.W. Johnson, C.L. Goodale, R.R. Blank, G. Fredriksen, W.W. Miller, J.D. Murphy, D.E. Todd, and R.F. Walker. 2011. Revisiting Soil Carbon and Nitrogen Sampling: Quantitative pits versus rotary cores. Soil Science 176(6): 273-279.

Rhoads, A.G. 2005. The effects of natural and anthropogenic disturbance on the composition and structure of the northern hardwood forest.

Richter, D.D., K.S. King, and J. Witter. 1989. Moisture and nutrient status of extremely acid Umbrepts in the Black Mountains of North Carolina. Soil Science Society of America Journal 53: 1222-1228.

Schaller, M., J.D. Blum, S.P. Hamburg, and M.A. Vadeboncoeur. 2010. Spatial variability of long-term chemical weathering rates in the White Mountains, New Hampshire, USA. Geoderma 154(3-4): 294-301.

Schmidt, M.W.I., M.S. Torn, S. Abiven, T. Dittmar, G. Guggenberger, I.A. Janssens, M. Kleber, I. Kögel-
Knabner, J. Lehmann, D.A.C. Manning, P. Nannipieri, D.P. Rasse, S. Weiner, and S.E. Trumbore. 2011. Persistence of soil organic matter as an ecosystem property. Nature 478(7367): 49-56.

Smith, R.J. 1993. Logarithmic transformation bias in allometry. American Journal of Physical Anthropology 90(2): 215-228.

Tan, K.H. 1996. Soil Sampling, Preparation, and Analysis. Marcel Dekker, Inc, New York.

Telford, W.M., L.P. Geldart, and R.E. Sheriff. 1990. Applied Geophysics. Cambridge University Press, Cambridge, UK.

Whitney, N., and D. Zabowski. 2004. Total Soil Nitrogen in the Coarse Fraction and at Depth. Soil Science Society of America Journal 68(2): 612-619.

Wibiralske, A.W., R.E. Latham, and A.H. Johnson. 2004. A biogeochemical analysis of the Pocono till barrens and adjacent hardwood forest underlain by Wisconsinan and Illinoian till in northeastern Pennsylvania. Canadian Journal of Forest Research 34(9): 1819-1832.

Yanai, R.D., M.A. Arthur, T.G. Siccama, and C.A. Federer. 2000. Challenges of measuring forest floor organic matter dynamics: Repeated measures from a chronosequence. Forest Ecology and Management 138(1-3): 273-283.

Yanai, R.D., W.S. Currie, and C.L. Goodale. 2003a. Soil Carbon Dynamics after Forest Harvest: An Ecosystem Paradigm Reconsidered. Ecosystems 6(3): 197-212.

Yanai, R.D., B.B. Park, and S.P. Hamburg. 2006. The vertical and horizontal distribution of roots in northern hardwood stands of varying age. Canadian Journal of Forest Research 36(2): 450-459.

Yanai, R.D., T.G. Siccama, M.A. Arthur, C.A. Federer, and A.J. Friedland. 1999. Accumulation and depletion of base cations in forest floors in the northeastern United States. Ecology 80(8): 2774-2787.

Yanai, R.D., S.V. Stehman, M.A. Arthur, C.E. Prescott, A.J. Friedland, T.G. Siccama, and D. Binkley. 2003b. Detecting Change in Forest Floor Carbon. Soil Science Society of America Journal 67: 1583-1593. 
Table 1. Soil depth, coarse fraction, and mass by horizon at each of 14 forested sites in central New Hampshire sampled using the quantitative pit method in 2003 and 2004. In each site, $n=3$ except where SD is not calculated $\left({ }^{*}\right)$ for samples taken from only one pit per site.

\begin{tabular}{|c|c|c|c|c|c|c|c|c|c|c|c|c|c|c|c|}
\hline \multirow[t]{2}{*}{$\underline{\text { Year }}$} & \multirow[t]{2}{*}{$\underline{\text { Site }}$} & \multicolumn{2}{|c|}{$\begin{array}{l}\text { O horiz depth } \\
(\mathrm{cm})\end{array}$} & \multicolumn{2}{|c|}{$\begin{array}{c}\text { O horizon mass } \\
<6 \mathrm{~mm}^{-2} \\
\left(\mathrm{~kg} \mathrm{~m}^{-2}\right)\end{array}$} & \multicolumn{2}{|c|}{$\begin{array}{c}\text { Min. soil depth } \\
\text { to C horizon } \\
(\mathrm{cm})\end{array}$} & \multicolumn{2}{|c|}{$\begin{array}{c}\text { Min. soil } \\
\text { coarse fraction } \\
(\% \text { vol })\end{array}$} & \multicolumn{2}{|c|}{$\begin{array}{c}\text { Min. soil } \\
<2 \mathrm{~mm} \text { mass } \\
\text { to } \mathrm{C} \text { horizon } \\
\left(\mathrm{kg} \mathrm{m}^{-2}\right)\end{array}$} & \multicolumn{2}{|c|}{$\begin{array}{c}\mathrm{C} 0-25 \mathrm{~cm} \\
<2 \mathrm{~mm} \mathrm{mass}^{-2} \\
\left(\mathrm{~kg} \mathrm{~m}^{-2}\right)\end{array}$} & \multicolumn{2}{|c|}{$\begin{array}{c}\text { C } 0-25 \mathrm{~cm} \\
\text { coarse fraction } \\
(\% \text { vol })\end{array}$} \\
\hline & & mean & $\underline{\mathrm{SD}}$ & mean & $\underline{\mathrm{SD}}$ & mean & $\underline{\mathrm{SD}}$ & mean & $\underline{\mathrm{SD}}$ & mean & $\underline{\mathrm{SD}}$ & mean & $\underline{\mathrm{SD}}$ & mean & $\underline{\mathrm{SD}}$ \\
\hline \multirow[t]{8}{*}{2003} & B1 & 5.0 & 0.8 & 5.2 & 1.2 & 35.5 & 10.9 & $19 \%$ & $14 \%$ & 224 & 54 & 319 & * & $18 \%$ & 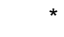 \\
\hline & BW & 12.4 & 2.7 & 19.2 & 13.9 & 30.3 & 10.2 & $26 \%$ & $14 \%$ & 188 & 54 & 368 & * & $25 \%$ & * \\
\hline & $\mathrm{H} 1$ & 5.4 & 4.4 & 12.3 & 9.4 & 68.3 & 25.0 & $14 \%$ & $8 \%$ & 591 & 262 & 249 & * & $35 \%$ & * \\
\hline & $\mathrm{H} 4$ & 4.4 & 1.3 & 5.6 & 3.7 & 72.9 & 16.5 & $25 \%$ & $11 \%$ & 522 & 130 & 36 & * & $54 \%$ & * \\
\hline & $\mathrm{H} 6$ & 13.2 & 4.6 & 31.6 & 15.0 & 61.3 & 36.9 & $17 \%$ & $7 \%$ & 539 & 322 & 200 & * & $54 \%$ & * \\
\hline & M5 & 7.0 & 1.6 & 5.8 & 3.0 & 48.0 & 4.0 & $36 \%$ & $7 \%$ & 273 & 78 & 0 & 0 & -- & \\
\hline & M6 & 5.2 & 2.9 & 7.9 & 2.3 & 65.9 & 6.4 & $34 \%$ & $17 \%$ & 371 & 131 & 171 & * & $38 \%$ & * \\
\hline & T30 & 5.7 & 3.8 & 7.2 & 3.1 & 47.6 & 29.9 & $23 \%$ & $8 \%$ & 309 & 159 & 273 & * & $46 \%$ & * \\
\hline \multirow[t]{6}{*}{2004} & C1 & 2.3 & 0.4 & 7.1 & 4.8 & 74.2 & 9.1 & $36 \%$ & $13 \%$ & 406 & 188 & 153 & 85 & $50 \%$ & $13 \%$ \\
\hline & C2 & 4.5 & 2.5 & 9.7 & 1.9 & 72.6 & 26.1 & $26 \%$ & $11 \%$ & 428 & 107 & 196 & 69 & $37 \%$ & $5 \%$ \\
\hline & C4 & 5.0 & 3.3 & 10.4 & 5.7 & 77.6 & 19.7 & $15 \%$ & $1 \%$ & 534 & 174 & 229 & 26 & $15 \%$ & $2 \%$ \\
\hline & C6 & 6.3 & 2.4 & 9.2 & 4.2 & 38.5 & 31.3 & $15 \%$ & $18 \%$ & 252 & 193 & 243 & 49 & $7 \%$ & $0 \%$ \\
\hline & C8 & 3.5 & 1.6 & 8.6 & 3.5 & 73.8 & 32.5 & $31 \%$ & $21 \%$ & 436 & 181 & 265 & 54 & $34 \%$ & $35 \%$ \\
\hline & C9 & 7.7 & 3.9 & 13.3 & 6.2 & 85.2 & 9.3 & $33 \%$ & $18 \%$ & 503 & 140 & 212 & 91 & $39 \%$ & $25 \%$ \\
\hline
\end{tabular}


Table 2. O horizon $\mathrm{C}$ and $\mathrm{N}$ stocks at each of 14 forested sites in central New Hampshire sampled using the quantitative pit method in 2003 and 2004. In each site, $n=3$ pits. In 2004, Oie samples were not sieved; the fine and coarse fractions were analyzed together. The subsamples of Oie and Oa processed for $\mathrm{C}$ and $\mathrm{N}$ analysis include roots; here we subtract the roots analyzed from a different subsample.

a. O horizon carbon content $\left(\mathrm{g} \mathrm{m}^{-2}\right)$.

\begin{tabular}{|c|c|c|c|c|c|c|c|c|c|c|c|c|c|c|c|}
\hline \multirow{2}{*}{\multicolumn{2}{|c|}{ Year Site }} & \multicolumn{2}{|c|}{$\begin{array}{c}\text { fine Oie } \\
\text { (forced through } \\
6 \mathrm{~mm} \text { sieve; minus } \\
\text { roots) }\end{array}$} & \multirow{2}{*}{$\begin{array}{c}\begin{array}{c}\text { coarse } \\
\text { Oie } \\
(>6 \mathrm{~mm})\end{array} \\
\underline{\text { mean } \underline{\mathrm{SD}}}\end{array}$} & \multicolumn{2}{|c|}{$\begin{array}{c}\text { total Oie } \\
\text { (minus roots) }\end{array}$} & \multicolumn{2}{|c|}{$\begin{array}{c}\begin{array}{c}\text { Oie fine } \\
\text { roots }\end{array} \\
\end{array}$} & \multicolumn{2}{|c|}{$\begin{array}{c}\text { fine Oa } \\
(<6 \mathrm{~mm}, \text { minus } \\
\text { roots) } \\
\end{array}$} & \multirow{2}{*}{$\frac{\begin{array}{c}\text { coarse Oa } \\
(>6 \mathrm{~mm})\end{array}}{\text { mean }}$} & \multicolumn{2}{|c|}{$\begin{array}{c}\text { fine root Oa } \\
\text { (passed } 6 \mathrm{~mm} \text { field } \\
\text { sieve) }\end{array}$} & \multicolumn{2}{|c|}{$\begin{array}{c}\text { coarse root Oa (did } \\
\text { not pass } 6 \mathrm{~mm} \text { field } \\
\text { sieve) }\end{array}$} \\
\hline & & mean & $\underline{\mathrm{SD}}$ & & mean & $\underline{\mathrm{SD}}$ & mean & $\underline{\mathrm{SD}}$ & mean & $\underline{\mathrm{SD}}$ & & mean & $\underline{\mathrm{SD}}$ & mean & $\underline{\mathrm{SD}}$ \\
\hline 2003 & B1 & 1095 & 75 & 17928 & 1274 & 80 & 11 & 4 & 1268 & 520 & 22 & 48 & 26 & 54 & 37 \\
\hline & BW & 1665 & 666 & 221118 & 1886 & 676 & 61 & 44 & 3902 & 1605 & 106 & 166 & 77 & 1027 & 825 \\
\hline & $\mathrm{H} 1$ & 387 & 13 & $74 \quad 15$ & 462 & 20 & 2 & 1 & 3695 & 3987 & 7 & 119 & * & 137 & * \\
\hline & $\mathrm{H} 4$ & 799 & 487 & 245152 & 1043 & 510 & 22 & 15 & 932 & 843 & 101 & 50 & 29 & 70 & 29 \\
\hline & $\mathrm{H} 6$ & 886 & 178 & 19943 & 1085 & 184 & 16 & 10 & 9540 & 3510 & 167 & 142 & 50 & 287 & 179 \\
\hline & M5 & 746 & 357 & 245129 & 991 & 380 & 6 & 5 & 1277 & 1265 & 56 & 56 & 22 & 699 & 824 \\
\hline & M6 & 1067 & 299 & 266150 & 1333 & 335 & 16 & 12 & 1856 & 916 & 4 & 82 & 22 & 128 & 90 \\
\hline & T30 & 1249 & 792 & 358225 & 1607 & 823 & 52 & 43 & 1444 & 1126 & 21 & 158 & 158 & 106 & 65 \\
\hline 2004 & C1 & -- & & -- & 412 & 202 & 8 & 7 & 580 & 184 & -- & 25 & 5 & 80 & 88 \\
\hline & $\mathrm{C} 2$ & -- & & -- & 997 & 421 & 42 & 30 & 2316 & 938 & -- & 45 & 25 & 240 & 182 \\
\hline & C4 & -- & & -- & 860 & 279 & 90 & 129 & 2299 & 2555 & -- & 103 & 92 & 303 & 126 \\
\hline & $\mathrm{C} 6$ & -- & & -- & 1061 & 352 & 116 & 67 & 2223 & 1398 & -- & 73 & 44 & 277 & 203 \\
\hline & $\mathrm{C} 8$ & -- & & -- & 410 & 81 & 36 & 6 & 1225 & 686 & -- & 57 & 17 & 129 & 86 \\
\hline & C9 & -- & & -- & 860 & 417 & 88 & 67 & 2145 & 1220 & -- & 78 & 29 & 284 & 260 \\
\hline
\end{tabular}

b. O horizon nitrogen content $\left(\mathrm{g} \mathrm{m}^{-2}\right)$.

\begin{tabular}{|c|c|c|c|c|c|c|c|c|c|c|c|c|c|c|c|}
\hline \multirow{2}{*}{\multicolumn{2}{|c|}{$\underline{\text { Year }} \underline{\text { Site }}$}} & \multicolumn{2}{|c|}{$\begin{array}{c}\text { fine Oie } \\
\text { (forced through } \\
6 \mathrm{~mm} \text { sieve; minus } \\
\text { roots) }\end{array}$} & \multirow{2}{*}{$\begin{array}{c}\begin{array}{c}\text { coarse } \\
\text { Oie } \\
(>6 \mathrm{~mm})\end{array} \\
\text { mean } \underline{\mathrm{SD}}\end{array}$} & \multicolumn{2}{|c|}{$\begin{array}{c}\text { total Oie } \\
\text { (minus roots) }\end{array}$} & \multicolumn{2}{|c|}{$\begin{array}{l}\text { Oie fine } \\
\text { roots }\end{array}$} & \multicolumn{2}{|c|}{$\begin{array}{c}\text { fine } \mathrm{Oa} \\
(<6 \mathrm{~mm}, \\
\text { minus roots) }\end{array}$} & \multirow{2}{*}{$\frac{\begin{array}{c}\text { coarse Oa } \\
(<6 \mathrm{~mm})\end{array}}{\underline{\text { mean }}}$} & \multicolumn{2}{|c|}{$\begin{array}{c}\text { fine root Oa } \\
\text { (passed 6mm field } \\
\text { sieve) } \\
\end{array}$} & \multicolumn{2}{|c|}{$\begin{array}{l}\text { coarse root Oa (did } \\
\text { not pass } 6 \mathrm{~mm} \text { field } \\
\text { sieve) }\end{array}$} \\
\hline & & mean & $\underline{\mathrm{SD}}$ & & mean & $\underline{\mathrm{SD}}$ & mean & $\underline{\mathrm{SD}}$ & mean & $\underline{\mathrm{SD}}$ & & mean & $\underline{\mathrm{SD}}$ & mean & $\underline{\mathrm{SD}}$ \\
\hline \multirow[t]{8}{*}{2003} & B1 & 37 & 0.4 & 1.80 .1 & 39 & 0.5 & 0.3 & 0.1 & 50 & 20 & 0.2 & 0.8 & 0.4 & 1.0 & 0.4 \\
\hline & BW & 63 & 22 & 2.81 .9 & 65 & 22 & 1.4 & 1.1 & 178 & 73 & 0.8 & 2.3 & 0.9 & 11.4 & 8.6 \\
\hline & $\mathrm{H} 1$ & 15 & 2 & 1.10 .4 & 16 & 2 & 0.04 & 0.01 & 160 & 169 & 0.2 & 1.5 & 0.0 & 1.8 & 0.0 \\
\hline & $\mathrm{H} 4$ & 32 & 20 & 3.72 .4 & 35 & 20 & 0.4 & 0.3 & 39 & 35 & 1.4 & 0.8 & 0.6 & 1.0 & 0.3 \\
\hline & $\mathrm{H} 6$ & 40 & 9 & 3.51 .2 & 43 & 9 & 0.3 & 0.2 & 350 & 136 & 2.1 & 2.0 & 0.7 & 3.6 & 1.9 \\
\hline & M5 & 31 & 15 & 3.11 .8 & 34 & 16 & 0.1 & 0.1 & 77 & 71 & 0.6 & 0.8 & 0.3 & 8.2 & 8.6 \\
\hline & M6 & 52 & 14 & 3.10 .5 & 55 & 14 & 0.3 & 0.2 & 88 & 42 & 0.1 & 1.4 & 0.5 & 1.6 & 1.0 \\
\hline & T30 & 57 & 34 & 6.03 .5 & 63 & 34 & 1.0 & 0.7 & 62 & 44 & 0.4 & 3.0 & 3.6 & 1.4 & 0.7 \\
\hline \multirow[t]{6}{*}{2004} & C1 & -- & & -- & 14 & 6 & 0.1 & 0.1 & 24 & 8 & -- & 0.4 & 0.1 & 1.0 & 0.9 \\
\hline & $\mathrm{C} 2$ & -- & & -- & 19 & 10 & 0.7 & 0.4 & 89 & 36 & -- & 0.7 & 0.3 & 2.9 & 1.9 \\
\hline & C4 & -- & & -- & 26 & 14 & 1.1 & 1.3 & 95 & 105 & -- & 1.5 & 1.2 & 3.5 & 1.3 \\
\hline & C6 & -- & & -- & 44 & 16 & 1.6 & 0.8 & 98 & 56 & -- & 1.4 & 0.9 & 3.3 & 2.1 \\
\hline & C8 & -- & & -- & 14 & 2 & 0.6 & 0.1 & 55 & 27 & -- & 1.0 & 0.2 & 2.0 & 1.0 \\
\hline & C9 & -- & & -- & 31 & 13 & 1.7 & 1.4 & 102 & 53 & -- & 1.4 & 0.6 & 3.9 & 2.8 \\
\hline
\end{tabular}


Table 3. Mineral soil $\mathrm{C}$ and $\mathrm{N}$ stocks of 14 forested sites in central New Hampshire sampled using the quantitative pit method in 2003 and 2004. For mineral soil, $n=3$ at all sites; $n=1$ for all $C 25-50 \mathrm{~cm}$ layers; and $n$ varies as noted in the $\mathrm{C} 0-25 \mathrm{~cm}$ layers. "BD" indicates that concentrations were below the detection limit.

a. Mineral soil carbon content $\left(\mathrm{g} \mathrm{m}^{-2}\right)$.

\begin{tabular}{|c|c|c|c|c|c|c|c|c|c|c|c|c|c|c|}
\hline \multirow{2}{*}{\multicolumn{2}{|c|}{$\underline{\text { Year }} \underline{\text { Site }}$}} & \multicolumn{2}{|c|}{ Mineral soil } & \multicolumn{2}{|c|}{$\begin{array}{l}\text { Mineral soil } \\
\text { roots }\end{array}$} & \multicolumn{3}{|c|}{$\begin{array}{c}\begin{array}{c}C-25 \mathrm{~cm} \\
\text { soil }\end{array} \\
\end{array}$} & \multicolumn{2}{|c|}{$\begin{array}{l}\text { C } 0-25 \mathrm{~cm} \\
\text { roots }\end{array}$} & $\begin{array}{c}\text { C 25-50 cm } \\
\text { soil }\end{array}$ & \multirow{2}{*}{$\begin{array}{r}\begin{array}{c}\text { C } 25-50 \mathrm{~cm} \\
\text { roots }\end{array} \\
\underline{\text { mean }}\end{array}$} & \multirow{2}{*}{$\begin{array}{r}\begin{array}{c}\text { fines on coarse } \\
\text { fraction }\end{array} \\
\underline{\text { mean }}\end{array}$} & \multirow{2}{*}{$\begin{array}{c}\begin{array}{l}\text { washed coarse } \\
\text { fraction }\end{array} \\
\text { mean }\end{array}$} \\
\hline & & mean & $\underline{\mathrm{SD}}$ & mean & $\underline{\mathrm{SD}}$ & $\underline{n}$ & mean & $\underline{\mathrm{SD}}$ & mean & $\underline{\mathrm{SD}}$ & mean & & & \\
\hline \multirow[t]{8}{*}{2003} & B1 & 8949 & 2248 & 1161 & 499 & 1 & 897 & * & 5 & * & 347 & 0 & -- & -- \\
\hline & BW & 6500 & 3392 & 624 & 544 & 1 & 690 & * & 0 & * & 136 & 0 & -- & -- \\
\hline & $\mathrm{H} 1$ & 11360 & 3289 & 1289 & 608 & 1 & 897 & * & 52 & * & 554 & 29 & 323 & -- \\
\hline & $\mathrm{H} 4$ & 12955 & 4569 & 1852 & 1068 & 1 & 725 & * & 208 & * & 0 & 0 & 1056 & -- \\
\hline & $\mathrm{H} 6$ & 9088 & 4125 & 288 & 45 & 1 & 570 & * & 18 & * & 466 & 14 & -- & -- \\
\hline & M5 & 7400 & 1977 & 1008 & 820 & 0 & 0 & 0 & 0 & 0 & 0 & 0 & -- & -- \\
\hline & M6 & 13454 & 4958 & 636 & 165 & 1 & 1706 & * & 33 & * & 515 & 18 & -- & -- \\
\hline & T30 & 7398 & 2989 & 795 & 81 & 1 & 2705 & * & 64 & * & 1883 & 14 & -- & -- \\
\hline \multirow[t]{6}{*}{2004} & $\mathrm{C} 1$ & 7302 & 1602 & 1225 & 526 & 3 & 418 & 104 & 20 & 9 & 467 & 32 & -- & -- \\
\hline & $\mathrm{C} 2$ & 7512 & 792 & 844 & 154 & 3 & 597 & 299 & 41 & 31 & 124 & 8 & -- & -- \\
\hline & $\mathrm{C} 4$ & 9331 & 163 & 1390 & 436 & 3 & 604 & 355 & 79 & 47 & 641 & 23 & -- & 860 \\
\hline & C6 & 8864 & 4087 & 754 & 77 & 3 & 3217 & 1062 & 127 & 70 & 2364 & 85 & -- & -- \\
\hline & C8 & 6356 & 2003 & 913 & 132 & 2 & 479 & 22 & 19 & 17 & 39 & 1 & -- & 410 \\
\hline & $\mathrm{C9}$ & 9349 & 2079 & 1214 & 146 & 3 & 446 & 320 & 24 & 16 & 210 & 2 & -- & - \\
\hline
\end{tabular}

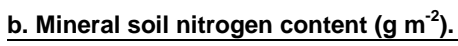

\begin{tabular}{|c|c|c|c|c|c|c|c|c|c|c|c|c|c|}
\hline \multirow{2}{*}{\multicolumn{2}{|c|}{$\underline{\text { Year }} \underline{\text { Site }}$}} & \multicolumn{2}{|c|}{ Mineral soil } & \multicolumn{2}{|c|}{$\begin{array}{l}\text { Mineral soil } \\
\text { roots }\end{array}$} & \multicolumn{2}{|c|}{$\begin{array}{c}\mathrm{C} 0-25 \mathrm{~cm} \\
\text { soil }\end{array}$} & \multicolumn{2}{|c|}{$\begin{array}{l}\mathrm{C} 0-25 \mathrm{~cm} \\
\text { roots }\end{array}$} & \multirow{2}{*}{$\begin{array}{l}\begin{array}{c}\text { C } 25-50 \mathrm{~cm} \\
\text { soil }\end{array} \\
\underline{\text { mean }}\end{array}$} & \multirow{2}{*}{$\begin{array}{c}\text { C } 25-50 \mathrm{~cm} \\
\text { roots } \\
\text { mean }\end{array}$} & \multirow{2}{*}{$\begin{array}{r}\begin{array}{c}\text { fines on coarse } \\
\text { fraction }\end{array} \\
\underline{\text { mean }}\end{array}$} & \multirow{2}{*}{$\begin{array}{c}\begin{array}{c}\text { washed coarse } \\
\text { fraction }\end{array} \\
\text { mean }\end{array}$} \\
\hline & & mean & $\underline{\mathrm{SD}}$ & $\underline{\text { mean }}$ & $\underline{\mathrm{SD}}$ & $\underline{\text { mean }}$ & $\underline{\mathrm{SD}}$ & mean & $\underline{\mathrm{SD}}$ & & & & \\
\hline \multirow[t]{8}{*}{2003} & $\mathrm{~B} 1$ & 444 & 69 & 14 & 7 & 40 & * & 0.1 & * & $\mathrm{BD}$ & 0 & -- & -- \\
\hline & BW & 286 & 92 & 7 & 6 & 18 & * & 0 & * & 17 & 0 & -- & -- \\
\hline & $\mathrm{H} 1$ & 458 & 145 & 14 & 6 & 53 & * & 0.6 & * & 30 & 0.4 & 17 & -- \\
\hline & $\mathrm{H} 4$ & 618 & 179 & 21 & 11 & 36 & * & 2.3 & * & 0 & 0 & 49 & -- \\
\hline & $\mathrm{H} 6$ & 381 & 92 & 3 & 0.5 & 31 & * & 0.2 & * & 32 & 0.2 & -- & -- \\
\hline & M5 & 458 & 75 & 11 & 9 & 0 & 0 & 0 & 0 & 0 & 0 & -- & -- \\
\hline & M6 & 634 & 265 & 7 & 2 & 85 & * & 0.4 & * & 15 & 0.2 & -- & -- \\
\hline & T30 & 381 & 138 & 9 & 1 & 89 & * & 0.8 & * & 42 & 0.2 & -- & -- \\
\hline \multirow[t]{6}{*}{2004} & $\mathrm{C} 1$ & 330 & 104 & 15 & 7 & 24 & 5.8 & 0.3 & 0.1 & 27 & 0.5 & -- & -- \\
\hline & $\mathrm{C} 2$ & 317 & 75 & 10 & 2 & 28 & 3.7 & 0.5 & 0.3 & $\mathrm{BD}$ & 0.1 & -- & -- \\
\hline & $\mathrm{C} 4$ & 381 & 21 & 17 & 5 & 22 & 20.1 & 1.0 & 0.5 & 31 & 0.3 & -- & 34 \\
\hline & $\mathrm{C} 6$ & 382 & 186 & 9 & 1 & 142 & 41.9 & 1.6 & 0.8 & 109 & 1.0 & -- & -- \\
\hline & $\mathrm{C} 8$ & 343 & 104 & 12 & 2 & 33 & 5.7 & 0.3 & 0.2 & $\mathrm{BD}$ & 0.02 & -- & 22 \\
\hline & $\mathrm{C9}$ & 523 & 148 & 15 & 2 & 26 & 16.5 & 0.3 & 0.2 & 16 & 0.02 & -- & - \\
\hline
\end{tabular}


Table 4. Comparison of soil mass and the associated coefficient of variation (CV) measured with quantitative pits at sites reported in the literature, including those reported in this study. Pit size and area sampled are listed in the appendix.

\begin{tabular}{|c|c|c|c|c|c|c|c|c|c|c|c|}
\hline \multirow[b]{2}{*}{ Reference } & \multirow[b]{2}{*}{$\begin{array}{r}\text { year } \\
\text { sampled } \\
\end{array}$} & \multirow[b]{2}{*}{ site } & \multirow[b]{2}{*}{$n$} & \multirow[b]{2}{*}{$\begin{array}{r}\text { pit size } \\
\left(\mathrm{m}^{2}\right)\end{array}$} & \multirow[b]{2}{*}{$\begin{array}{r}\text { Area } \\
\text { (ha) }\end{array}$} & \multicolumn{2}{|c|}{ O horizon } & \multicolumn{2}{|c|}{ Mineral soil } & \multicolumn{2}{|c|}{ Total } \\
\hline & & & & & & mean & $\mathrm{CV}$ & mean & $\mathrm{CV}$ & mean & $\mathrm{CV}$ \\
\hline This study & 2003 & B1 & 3 & 0.5 & 0.5 & 5.2 & $22 \%$ & 224 & $24 \%$ & 230 & $23 \%$ \\
\hline & & BW & 3 & 0.5 & 0.5 & 19.2 & $72 \%$ & 188 & $29 \%$ & 207 & $20 \%$ \\
\hline & & $\mathrm{H} 1$ & 3 & 0.5 & 0.5 & 12.3 & $77 \%$ & 591 & $44 \%$ & 603 & $42 \%$ \\
\hline & & $\mathrm{H} 4$ & 3 & 0.5 & 0.5 & 5.6 & $66 \%$ & 522 & $25 \%$ & 527 & $25 \%$ \\
\hline & & $\mathrm{H} 6$ & 3 & 0.5 & 0.5 & 31.6 & $48 \%$ & 539 & $60 \%$ & 570 & $56 \%$ \\
\hline & & M5 & 3 & 0.5 & 0.5 & 5.8 & $52 \%$ & 273 & $29 \%$ & 279 & $28 \%$ \\
\hline & & M6 & 3 & 0.5 & 0.5 & 7.9 & $30 \%$ & 371 & $35 \%$ & 379 & $34 \%$ \\
\hline & & T30 & 3 & 0.5 & 0.5 & 7.2 & $43 \%$ & 309 & $51 \%$ & 317 & $51 \%$ \\
\hline & 2004 & C1 & 3 & 0.5 & 0.75 & 7.1 & $68 \%$ & 406 & $46 \%$ & 413 & $44 \%$ \\
\hline & & $\mathrm{C} 2$ & 3 & 0.5 & 0.75 & 9.7 & $19 \%$ & 428 & $25 \%$ & 438 & $24 \%$ \\
\hline & & $\mathrm{C} 4$ & 3 & 0.5 & 0.75 & 10.4 & $54 \%$ & 534 & $33 \%$ & 545 & $31 \%$ \\
\hline & & C6 & 3 & 0.5 & 0.75 & 9.2 & $46 \%$ & 252 & $77 \%$ & 261 & $72 \%$ \\
\hline & & $\mathrm{C} 8$ & 3 & 0.5 & 0.75 & 8.6 & $40 \%$ & 436 & $41 \%$ & 445 & $40 \%$ \\
\hline & & $\mathrm{C9}$ & 3 & 0.5 & 0.75 & 13.3 & $47 \%$ & 503 & $28 \%$ & 516 & $26 \%$ \\
\hline \multirow[t]{10}{*}{$\begin{array}{r}\text { Unpublished resampling of } \\
\text { Hamburg 1984a }\end{array}$} & 1992 & Bald Mt 3 & 3 & 0.5 & 0.5 & 3.6 & $23 \%$ & 347 & $16 \%$ & 350 & $16 \%$ \\
\hline & & Bald Mt 4 & 3 & 0.5 & 0.5 & & & 389 & $10 \%$ & & \\
\hline & & Bald Mt 5 & 4 & 0.5 & 0.5 & 5.6 & $16 \%$ & 351 & $15 \%$ & 357 & $15 \%$ \\
\hline & & Bald Mt 6 & 3 & 0.5 & 0.5 & 10.3 & $8 \%$ & 304 & $15 \%$ & 314 & $14 \%$ \\
\hline & & Bald Mt 9 & 3 & 0.5 & 0.5 & & & 386 & $10 \%$ & & \\
\hline & 2005 & Bald Mt 3 & 3 & 0.5 & 0.5 & 5.1 & $66 \%$ & 469 & $24 \%$ & 475 & $24 \%$ \\
\hline & & Bald Mt 4 & 3 & 0.5 & 0.5 & & & 465 & $11 \%$ & & \\
\hline & & Bald Mt 5 & 3 & 0.5 & 0.5 & 6.2 & $40 \%$ & 425 & $27 \%$ & 431 & $27 \%$ \\
\hline & & Bald Mt 6 & 3 & 0.5 & 0.5 & 6.0 & $42 \%$ & 402 & $6 \%$ & 408 & $5 \%$ \\
\hline & & Bald Mt 9 & 3 & 0.5 & 0.5 & & & 458 & $16 \%$ & & \\
\hline \multirow[t]{3}{*}{ Johnson et al. 1995} & 1983 & W5 & 59 & 0.5 & 22 & 8.7 & $73 \%$ & 317 & $51 \%$ & 325 & $49 \%$ \\
\hline & 1986 & W5 & 60 & 0.5 & 22 & 11.9 & $102 \%$ & 337 & $50 \%$ & 349 & $47 \%$ \\
\hline & 1991 & W5 & 60 & 0.5 & 22 & 7.5 & $111 \%$ & 332 & $56 \%$ & 339 & $55 \%$ \\
\hline unpublished resampling & 1998 & W5 & 60 & 0.5 & 22 & 9.7 & $74 \%$ & 307 & $59 \%$ & 317 & $57 \%$ \\
\hline \multirow[t]{3}{*}{ Ross 2006} & 2005 & DSL & 3 & 0.5 & 0.36 & & & 1569 & $4 \%$ & & \\
\hline & & TNL & 3 & 0.5 & 0.36 & & & 1597 & $14 \%$ & & \\
\hline & & TSL & 3 & 0.5 & 0.36 & & & 1342 & $29 \%$ & & \\
\hline Fernandez et al. 1993 & $1987-8$ & all & 24 & 0.5 & 0.4 & 10.6 & $38 \%$ & & & 329 & $24 \%$ \\
\hline \multirow[t]{4}{*}{ Wibralske et al. 2004} & $1992-3$ & IB & 40 & 0.25 & 40600 & 20.0 & $38 \%$ & 496 & $16 \%$ & 516 & $15 \%$ \\
\hline & & WB & 20 & 0.25 & 40600 & 15.5 & $37 \%$ & 469 & $17 \%$ & 485 & $16 \%$ \\
\hline & & IF & 19 & 0.25 & 40600 & 12.2 & $52 \%$ & 564 & $11 \%$ & 577 & $11 \%$ \\
\hline & & WF & 20 & 0.25 & 40600 & 12.7 & $49 \%$ & 495 & $10 \%$ & 507 & $10 \%$ \\
\hline
\end{tabular}


Table 5. Soil carbon in organic horizon and mineral soil measured with quantitative pits at sites reported in the literature, including those reported in this study. For each site, we calculate the detectable change $(\alpha=0.05$, power $=0.75)$ if resampled with the same number of pits (det $\Delta)$, and the power to detect a $20 \%$ change with $95 \%$ confidence (pwr). Pit size and area sampled are listed in the appendix.

\begin{tabular}{|c|c|c|c|c|c|c|c|c|c|c|c|c|c|c|c|}
\hline \multirow[b]{2}{*}{ Reference } & \multirow[b]{2}{*}{ year } & \multirow[b]{2}{*}{ site } & \multirow[b]{2}{*}{$n$} & \multicolumn{4}{|c|}{ O Horizon } & \multicolumn{4}{|c|}{ Mineral soil } & \multicolumn{4}{|c|}{ Total } \\
\hline & & & & mean & CV & $\operatorname{det} \Delta$ & $\begin{array}{r}\text { pwr } \\
\text { to } \\
\text { detect } \\
\pm 20 \% \\
\end{array}$ & mean & CV & $\operatorname{det} \Delta$ & $\begin{array}{r}\text { pwr } \\
\text { to } \\
\text { detect } \\
\pm 20 \% \\
\end{array}$ & mean & $\mathrm{CV}$ & $\operatorname{det} \Delta$ & $\begin{array}{r}\text { pwr } \\
\text { to } \\
\text { detect } \\
\pm 20 \% \\
\end{array}$ \\
\hline \multirow[t]{14}{*}{ This study } & 2003 & B1 & 3 & 2422 & $23 \%$ & $66 \%$ & 0.13 & 8949 & $25 \%$ & $72 \%$ & 0.12 & 11371 & $23 \%$ & $67 \%$ & 0.13 \\
\hline & & BW & 3 & 5794 & $39 \%$ & $112 \%$ & 0.07 & 6500 & $52 \%$ & $150 \%$ & 0.06 & 12294 & $33 \%$ & $95 \%$ & 0.08 \\
\hline & & $\mathrm{H} 1$ & 3 & 4202 & $95 \%$ & $273 \%$ & 0.04 & 11360 & $29 \%$ & $83 \%$ & 0.10 & 15562 & $39 \%$ & $112 \%$ & 0.07 \\
\hline & & $\mathrm{H} 4$ & 3 & 1802 & $49 \%$ & $141 \%$ & 0.06 & 12955 & $35 \%$ & $101 \%$ & 0.08 & 14757 & $33 \%$ & $95 \%$ & 0.08 \\
\hline & & $\mathrm{H} 6$ & 3 & 10584 & $34 \%$ & $98 \%$ & 0.08 & 9088 & $45 \%$ & $131 \%$ & 0.06 & 19673 & $4 \%$ & $13 \%$ & 0.98 \\
\hline & & M5 & 3 & 2084 & $50 \%$ & $144 \%$ & 0.06 & 7400 & $27 \%$ & $77 \%$ & 0.11 & 9483 & $12 \%$ & $36 \%$ & 0.33 \\
\hline & & M6 & 3 & 3022 & $30 \%$ & $86 \%$ & 0.09 & 13454 & $37 \%$ & $106 \%$ & 0.08 & 16476 & $25 \%$ & $72 \%$ & 0.12 \\
\hline & & T30 & 3 & 2902 & $52 \%$ & $149 \%$ & 0.06 & 7398 & $40 \%$ & $116 \%$ & 0.07 & 10301 & $44 \%$ & $125 \%$ & 0.06 \\
\hline & 2004 & $\mathrm{C} 1$ & 3 & 1025 & $33 \%$ & $94 \%$ & 0.08 & 7302 & $22 \%$ & $63 \%$ & 0.14 & 8327 & $19 \%$ & $54 \%$ & 0.17 \\
\hline & & $\mathrm{C} 2$ & 3 & 3400 & $15 \%$ & $44 \%$ & 0.24 & 7512 & $11 \%$ & $30 \%$ & 0.43 & 10912 & $3 \%$ & $9 \%$ & $>0.99$ \\
\hline & & $\mathrm{C} 4$ & 3 & 3352 & $81 \%$ & $233 \%$ & 0.04 & 9331 & $2 \%$ & $5 \%$ & $>0.99$ & 12683 & $22 \%$ & $62 \%$ & 0.14 \\
\hline & & C6 & 3 & 3474 & $50 \%$ & $144 \%$ & 0.06 & 8864 & $46 \%$ & $133 \%$ & 0.06 & 12338 & $24 \%$ & $68 \%$ & 0.13 \\
\hline & & $\mathrm{C} 8$ & 3 & 1728 & $40 \%$ & $116 \%$ & 0.07 & 6356 & $32 \%$ & $91 \%$ & 0.09 & 8084 & $25 \%$ & $72 \%$ & 0.12 \\
\hline & & $\mathrm{C9}$ & 3 & 3171 & $34 \%$ & $97 \%$ & 0.08 & 9349 & $22 \%$ & $64 \%$ & 0.14 & 12520 & $10 \%$ & $29 \%$ & 0.46 \\
\hline \multirow{10}{*}{$\begin{array}{r}\text { Unpublished resampling } \\
\text { of Hamburg } 1984 a\end{array}$} & 1992 & 3 & 3 & 1493 & $25 \%$ & $71 \%$ & $\overline{0.12}$ & 12710 & $15 \%$ & $43 \%$ & 0.25 & 14202 & $15 \%$ & $43 \%$ & 0.24 \\
\hline & & 4 & 3 & & & & & 12446 & $9 \%$ & $25 \%$ & 0.58 & & & & \\
\hline & & 5 & 4 & 2122 & $27 \%$ & $60 \%$ & 0.14 & 9138 & $18 \%$ & $40 \%$ & 0.27 & 11260 & $18 \%$ & $40 \%$ & 0.26 \\
\hline & & 6 & 3 & 2934 & $20 \%$ & $58 \%$ & 0.15 & 16670 & $8 \%$ & $24 \%$ & 0.59 & 19604 & $9 \%$ & $25 \%$ & 0.56 \\
\hline & & 9 & 3 & & & & & 13385 & $9 \%$ & $26 \%$ & 0.54 & & & & \\
\hline & 2005 & 3 & 3 & 2099 & $69 \%$ & $199 \%$ & 0.05 & 14023 & $3 \%$ & $10 \%$ & $>0.99$ & 16123 & $10 \%$ & $28 \%$ & 0.48 \\
\hline & & 4 & 3 & & & & & 13450 & $14 \%$ & $39 \%$ & 0.29 & & & & \\
\hline & & 5 & 3 & 2525 & $48 \%$ & $137 \%$ & 0.06 & 9179 & $19 \%$ & $55 \%$ & 0.17 & 11704 & $10 \%$ & $28 \%$ & 0.48 \\
\hline & & 6 & 3 & 2423 & $33 \%$ & $94 \%$ & 0.09 & 14235 & $30 \%$ & $88 \%$ & 0.09 & 16658 & $25 \%$ & $72 \%$ & 0.12 \\
\hline & & 9 & 3 & & & & & 13897 & $25 \%$ & $73 \%$ & 0.11 & & & & \\
\hline \multirow[t]{4}{*}{ Johnson et al. 1995} & 1983 & W5 & 59 & 2997 & $76 \%$ & $37 \%$ & 0.29 & 13076 & $47 \%$ & $23 \%$ & 0.63 & 16106 & $38 \%$ & $18 \%$ & 0.82 \\
\hline & 1986 & W5 & 60 & 2925 & $112 \%$ & $54 \%$ & 0.16 & 14184 & $47 \%$ & $23 \%$ & 0.64 & 17208 & $37 \%$ & $18 \%$ & 0.83 \\
\hline & 1991 & W5 & 60 & 2165 & $105 \%$ & $51 \%$ & 0.18 & 11709 & $49 \%$ & $24 \%$ & 0.59 & 13874 & $45 \%$ & $22 \%$ & 0.67 \\
\hline & 1998 & W5 & 60 & 3140 & $85 \%$ & $41 \%$ & 0.25 & 11392 & $46 \%$ & $22 \%$ & 0.66 & 14532 & $37 \%$ & $18 \%$ & 0.85 \\
\hline \multirow[t]{3}{*}{ Ross 2006} & 2005 & DSL & 3 & & & & & 1189 & $17 \%$ & $50 \%$ & 0.19 & & & & \\
\hline & & $\mathrm{TNL}$ & 3 & & & & & 1226 & $34 \%$ & $97 \%$ & 0.08 & & & & \\
\hline & & TSL & 3 & & & & & 1280 & $38 \%$ & $110 \%$ & 0.07 & & & & \\
\hline Fernandez et al. 1993 & $1987-8$ & all & 24 & 4400 & $41 \%$ & $32 \%$ & 0.38 & & & & & 11100 & $26 \%$ & $20 \%$ & 0.75 \\
\hline \multirow[t]{3}{*}{ Bedison et al. 2009} & $2005-6$ & $\mathrm{NH}$ & 20 & 5800 & $17 \%$ & $15 \%$ & 0.94 & 22700 & $21 \%$ & $18 \%$ & 0.83 & 28500 & $17 \%$ & $15 \%$ & 0.96 \\
\hline & & $P$ & 10 & 2400 & $29 \%$ & $36 \%$ & 0.31 & 19700 & $12 \%$ & $15 \%$ & 0.93 & 22100 & $11 \%$ & $14 \%$ & 0.97 \\
\hline & & SF & 12 & 13300 & $16 \%$ & $18 \%$ & 0.85 & 6200 & $40 \%$ & $45 \%$ & 0.21 & 19500 & $11 \%$ & $12 \%$ & $>0.99$ \\
\hline Richter et al. 1989 & NR & ALL & 36 & & & & & & & & & 13500 & $27 \%$ & $17 \%$ & 0.87 \\
\hline Johnson et al. 2009 & $1990-2$ & ALL & 41 & & & & & 14750 & $35 \%$ & $21 \%$ & 0.73 & & & & \\
\hline Gaudinski et al. 2000 & 1996 & & 2 & & & & & & & & & 8800 & $15 \%$ & $79 \%$ & 0.13 \\
\hline \multirow[t]{2}{*}{ Johnson et al. 2011} & NR & $B$ & 43 & & & & & & & & & 10600 & $55 \%$ & $32 \%$ & 0.38 \\
\hline & & $\mathrm{P}$ & 53 & & & & & & & & & 8000 & $63 \%$ & $33 \%$ & 0.37 \\
\hline \multirow[t]{4}{*}{ Zummo \& Friedland 2011} & 2009 & LD & 4 & & & & & 9330 & $9 \%$ & $20 \%$ & 0.73 & & & & \\
\hline & & MD & 4 & & & & & 7980 & $12 \%$ & $26 \%$ & 0.54 & & & & \\
\hline & & $\mathrm{HD}$ & 4 & & & & & 7010 & $12 \%$ & $26 \%$ & 0.52 & & & & \\
\hline & & $\mathrm{M}$ & 4 & & & & & 8510 & $9 \%$ & $20 \%$ & 0.75 & & & & \\
\hline
\end{tabular}


Table 6. Comparison of root mass and coefficients of variation measured with quantitative pits at sites reported in the literature, including those reported in this study. For each site, we calculate the detectable change ( $\alpha=0.05$, power $=0.75$ ) if resampled with the same number of pits (det $\Delta$ ), and the power to detect a $20 \%$ change with $95 \%$ confidence (pwr). Pit size and area sampled are listed in the appendix.

\begin{tabular}{|c|c|c|c|c|c|c|c|c|}
\hline & Site & $\mathrm{n}$ & depth & mean & stdev & $\mathrm{CV}$ & $\operatorname{det} \Delta$ & $\begin{array}{l}\text { pwr to } \\
\text { detect } \\
\pm 20 \% \\
\end{array}$ \\
\hline \multirow[t]{14}{*}{ This study } & B1 & 3 & to top of C & 2642 & 896 & $34 \%$ & $98 \%$ & 0.09 \\
\hline & BW & 3 & “ “ & 3912 & 2628 & $67 \%$ & $193 \%$ & 0.06 \\
\hline & $\mathrm{H} 1$ & 3 & “ “ & 3423 & 818 & $24 \%$ & $69 \%$ & 0.13 \\
\hline & $\mathrm{H} 4$ & 3 & “ “ & 4154 & 2488 & $60 \%$ & $172 \%$ & 0.06 \\
\hline & $\mathrm{H} 6$ & 3 & “ “ & 1526 & 537 & $35 \%$ & $101 \%$ & 0.08 \\
\hline & M5 & 3 & “ “ & 2729 & 2457 & $90 \%$ & $259 \%$ & 0.05 \\
\hline & M6 & 3 & “ “ & 1797 & 203 & $11 \%$ & $33 \%$ & 0.38 \\
\hline & T30 & 3 & “" “ & 2314 & 762 & $33 \%$ & $95 \%$ & 0.09 \\
\hline & $\mathrm{C} 1$ & 3 & top of C & 3614 & 2232 & $62 \%$ & $178 \%$ & 0.06 \\
\hline & C2 & 3 & “ “ & 2524 & 580 & $23 \%$ & $66 \%$ & 0.13 \\
\hline & C4 & 3 & “ “ & 4094 & 881 & $22 \%$ & $62 \%$ & 0.14 \\
\hline & C6 & 3 & “ “ & 2808 & 440 & $16 \%$ & $45 \%$ & 0.23 \\
\hline & C8 & 3 & “ “ & 2404 & 322 & $13 \%$ & $39 \%$ & 0.29 \\
\hline & C9 & 3 & “ “ & 3864 & 973 & $25 \%$ & $73 \%$ & 0.12 \\
\hline Rau et al. 2009 & & 24 & $52 \mathrm{~cm}$ & 883 & 387 & $44 \%$ & $34 \%$ & 0.07 \\
\hline Fahey et al. 1988 & & 59 & to top of C & 2676 & 4105 & $153 \%$ & $75 \%$ & 0.05 \\
\hline $\begin{array}{r}\text { Fernandez et al. } \\
1993\end{array}$ & & 24 & to top of C & 1800 & 1314 & $73 \%$ & $56 \%$ & 0.06 \\
\hline
\end{tabular}


Figure 1. Map of central New Hampshire forest sites used in this study. Grayscale shading indicates elevation (darkest gray is $<200 \mathrm{~m}$; white is $>600 \mathrm{~m}$ ). The dashed line shows the White Mountain National Forest boundary, and the solid lines show Hubbard Brook (HBEF) and Bartlett Experimental Forests (BEF). Sites B1 and BW are at Bald Mountain.
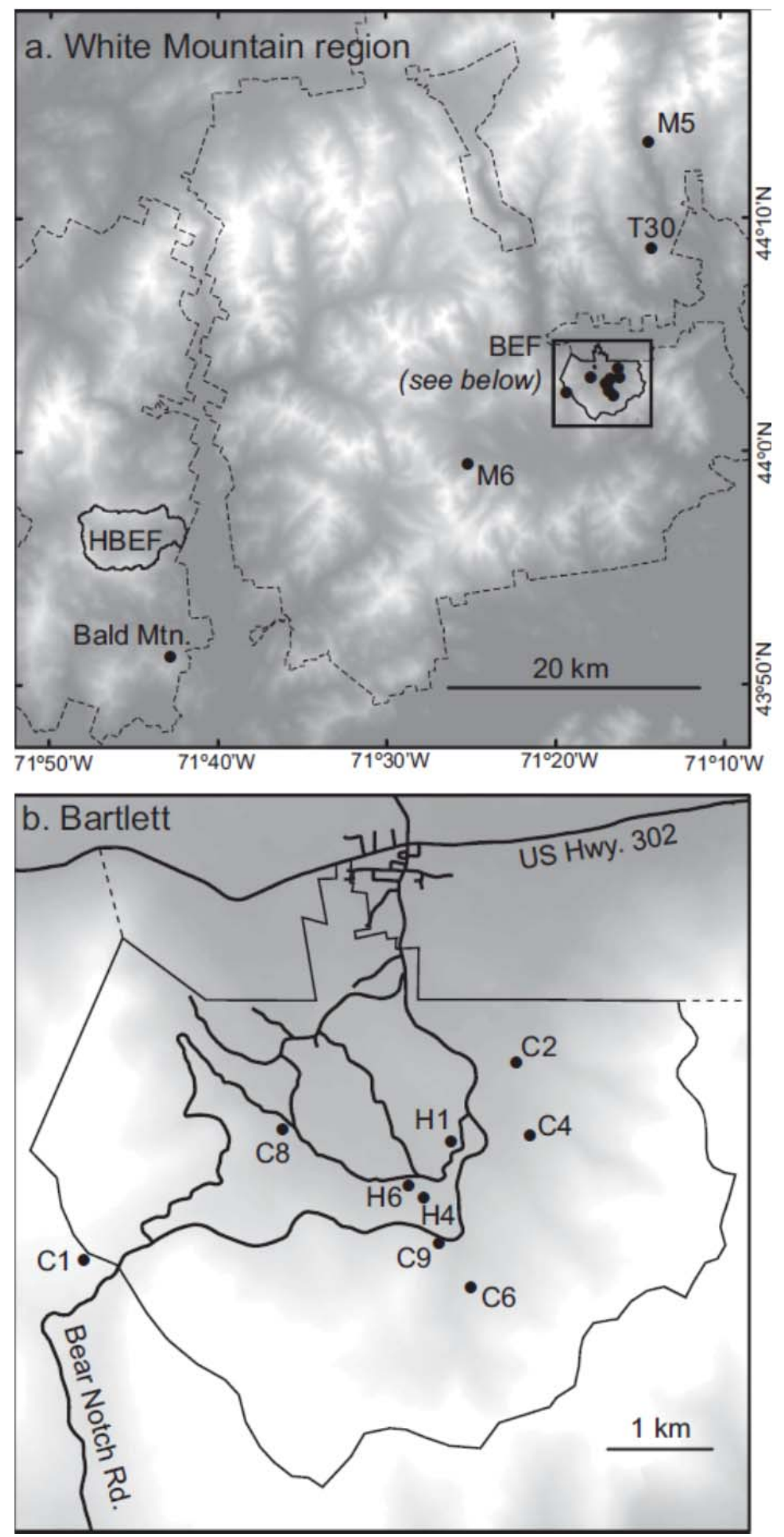
Figure 2. Bulk density and coarse fraction with depth in 14 forested sites using quantitative soil pits excavated in 2003-4. Open circles show $O$ horizon samples; filled circles show mineral soils, and filled squares show $\mathrm{C}$ horizon samples. Linear regressions are shown with $95 \%$ confidence intervals. $D=$ depth in $\mathrm{cm} ; \mathrm{BD}=$ bulk density in $\mathrm{g} \mathrm{cm}-$ 3; $C F=$ coarse fragment volume expressed as a fraction (e.g. $30 \%=0.30$ ).
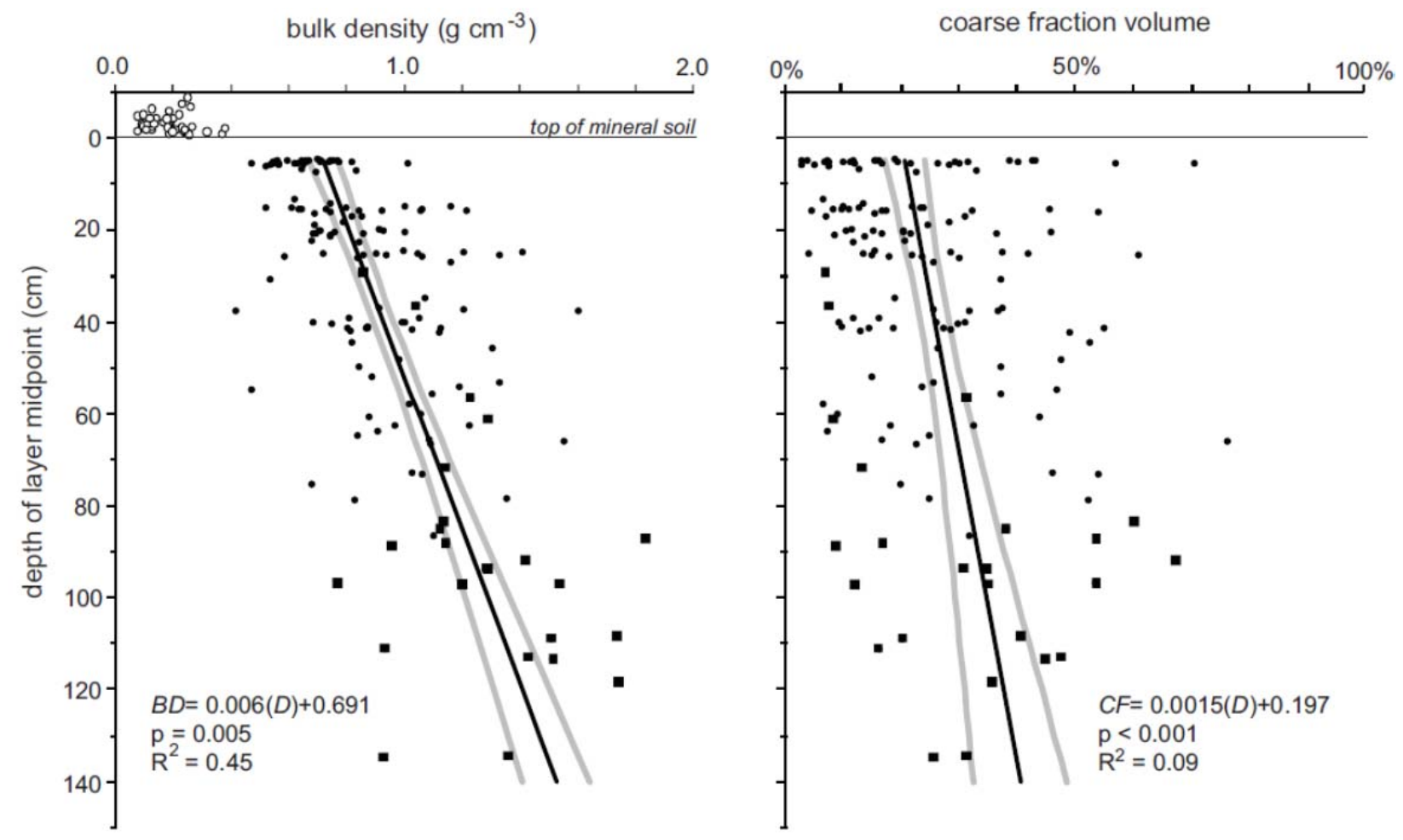
Figure 3. Mineral soil $\mathrm{C}$ and $\mathrm{N}$ concentrations with depth in 14 forested sites using quantitative soil pits dug in 2003-04, including both quantitative and non-quantitative C-horizon samples. Log-log regressions are shown with $95 \%$ confidence intervals, and are corrected for bias according to Smith (1993). D = depth in cm; C and N concentrations are expressed as fractions (e.g. $1 \%=0.01$ ).

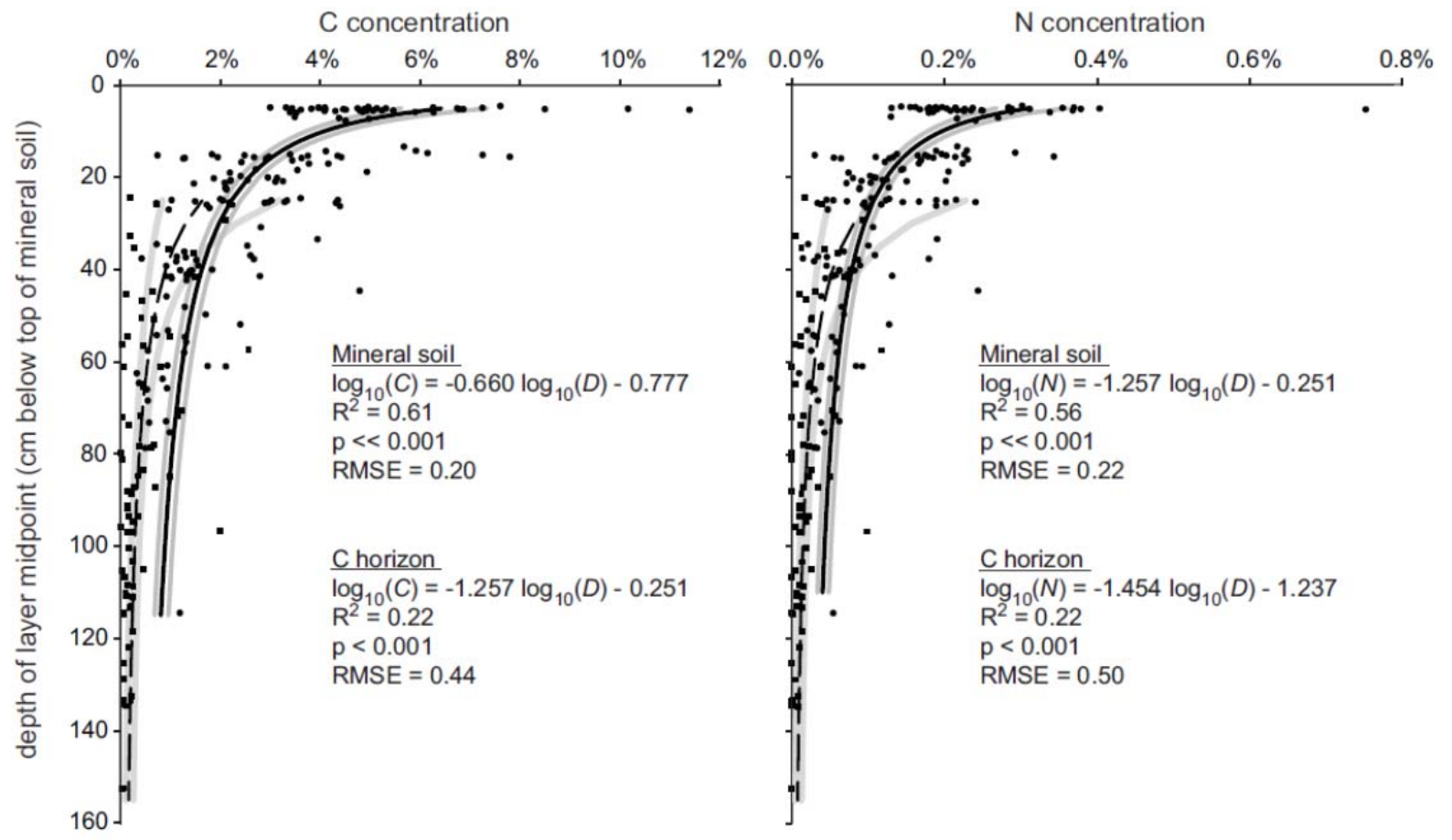


Figure 4. Total carbon by horizon across plotted against time since harvest at 14 forested sites using quantitative soil pits dug in 2003-04. Sites B1 and BW, with more complicated land-use history, are not included. Error bars show 1SD. Site M6 had an exceptionally thick O horizon (Table 1), perhaps due to its slope position.
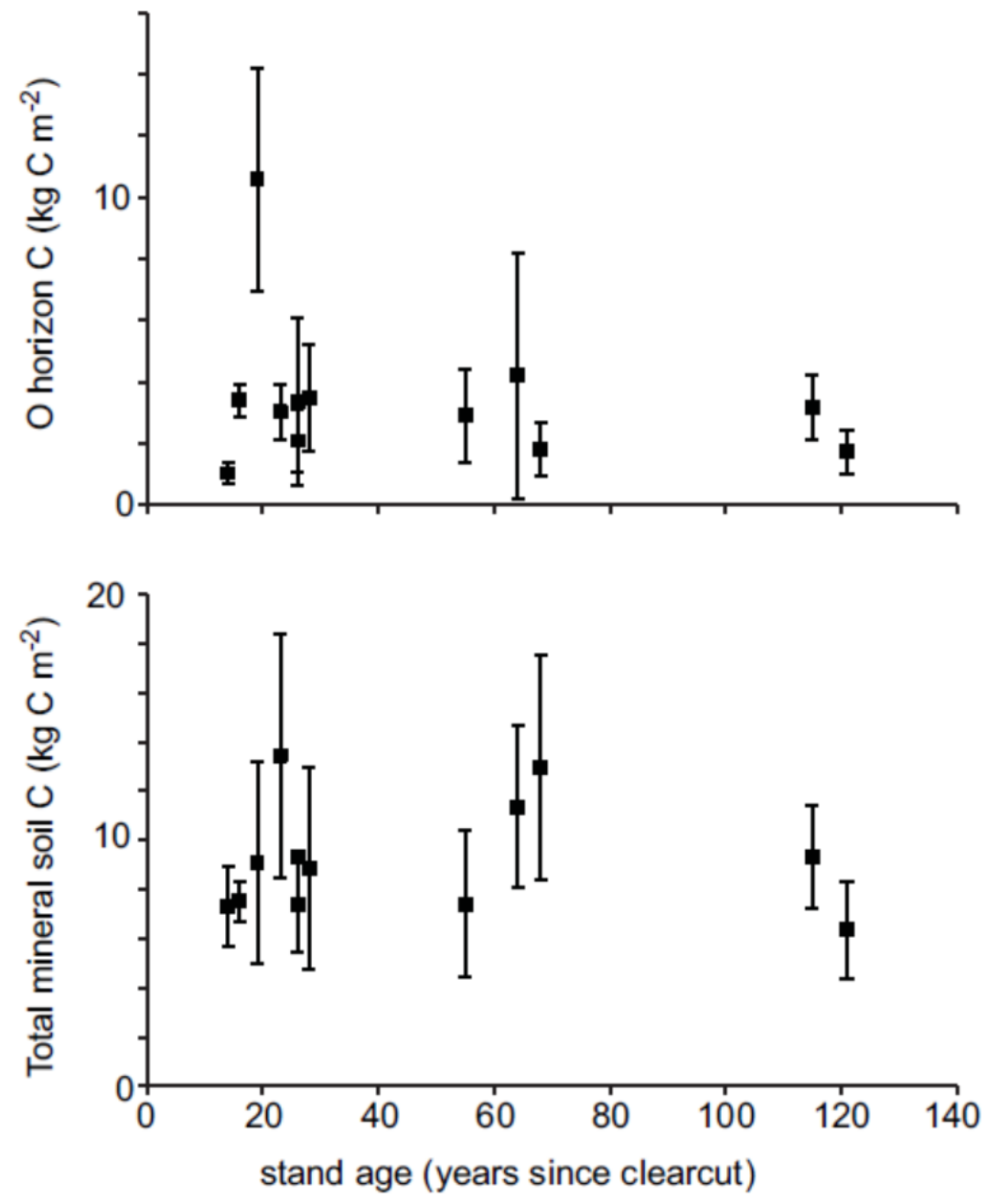
Appendix Table. Studies that have employed the quantitative pit method.

\begin{tabular}{|c|c|c|c|c|c|c|c|c|}
\hline \multirow{2}{*}{$\frac{\text { Reference }}{\text { Austin, } 2006}$} & Dig Date & $\begin{array}{l}\text { State or } \\
\text { country }\end{array}$ & \multicolumn{2}{|r|}{$\begin{array}{r}\text { Pit } \\
\text { size } \\
(\mathrm{m} 2)\end{array}$} & $\begin{array}{l}\text { number } \\
\text { of plots }\end{array}$ & \multicolumn{3}{|c|}{$\begin{array}{l}\text { total } \\
\text { pits pits/ha Volume Measurements }\end{array}$} \\
\hline & 2005 & $\mathrm{NH}$ & Campton and Thornton & 0.5 & 5 & 10 & NR & Frame grid \\
\hline Bedison and Johnson, 2009, 2010 & $2005-6$ & NY & Adirondack Park & 0.25 & 54 & 54 & NR & NR \\
\hline Canary et al., 2000 & NR & WA & Cascade Mtns & 0.25 & 3 & 9 & NR & Frame grid \\
\hline David et al., 1987 & 1982 & NY & Huntington Forest & 1 & & 2 & & NR \\
\hline Diochon and Kellman, 2008 & 2005 & NS & Liscomb Game Sanctuary & 0.5 & 5 & 15 & NR & Frame grid \\
\hline Fernandez et al., 1993 & $1987-8$ & ME & Howland Forest & 0.5 & 2 & 24 & 60 & Frame \\
\hline Fernandez et al., 2003 & 1998 & ME & Bear Brook & 0.5 & 2 & 80 & 60 & Frame \\
\hline Friedland et al., 1991 & $1985-7$ & NY & Whiteface Mtn & 0.5 & 4 & 13 & NR & Frame grid \\
\hline Gaudinski et al., 2000 & 1996 & MA & Harvard Forest & 0.25 & 2 & 2 & NR & Frame grid \\
\hline Hamburg, 1984a & 1980 & $\mathrm{NH}$ & Bald Mtn & 1 & 8 & 24 & 5.6 & Frame grid \\
\hline Hamburg unpublished & 1992 & $\mathrm{NH}$ & Bald Mtn & 0.5 & 5 & 15 & 5.6 & Frame grid \\
\hline Hamburg unpublished & 2005 & $\mathrm{NH}$ & Bald Mtn & 0.5 & 5 & 15 & 5.6 & Frame grid \\
\hline Harrison et al., 2003 & NR & WA & Cedar River watershed & 0.25 & 2 & 6 & NR & Frame grid \\
\hline Hofmeister et al., 2008 & $2003-5$ & Czech Rep & Načetín, Lysina & 0.5 & 4 & 26 & $25-50$ & Frame grid \\
\hline Hooker and Compton, 2003 & 1998 & $\mathrm{RI}$ & Scituate watershed & 0.25 & 12 & 36 & 33 & Frame grid \\
\hline Huntington and Ryan, 1990 & $1986-7$ & $\mathrm{NH}$ & Mt. Moosilauke & 0.5 & 9 & 36 & NR & NR \\
\hline Huntington et al., 1988 & 1983 & $\mathrm{NH}$ & W5, Hubbard Brook Exp. Forest & 0.5 & & 59 & 2.6 & Frame grid \\
\hline Huntington et al., 1989 & 1986 & $\mathrm{NH}$ & W5, Hubbard Brook Exp. Forest & 0.5 & & 60 & 2.6 & Frame grid \\
\hline Johnson CE, 1995 & 1991 & $\mathrm{NH}$ & W5, Hubbard Brook Exp. Forest & 0.5 & & 60 & 2.6 & Frame grid \\
\hline Johnson CE unpublished & 1997 & $\mathrm{NH}$ & W1, Hubbard Brook Exp. Forest & 0.5 & 1 & 12 & 1 & Frame grid \\
\hline Johnson CE unpublished & 2011 & NY & Catskills Mtns & 0.5 & & 50 & & Frame grid \\
\hline Johnson DW et al., 1997 & NR & NV\&CA & Little Valley and Sagehen Creek & 0.25 & 2 & 8 & NR & calc from BD \\
\hline Johnson DW et al., 2007 & 2002 & NV & Gondola wildfire site & NR & 14 & 14 & NR & calc from BD \\
\hline Johnson DW et al., 2008 & 2001 & $\mathrm{CA}$ & Tahoe National Forest & NR & 3 & 30 & NR & calc from BD \\
\hline Johnson DW et al., 2011 & NR & $\mathrm{CA}$ & Kings River Exp. Watersheds & NR & 8 & 87 & 0.1 & calc from BD \\
\hline Johnson KD et al., 2009 & $1990-2$ & VT & Green Mtns & 0.25 & 41 & 41 & NR & NR \\
\hline Krám et al., 1997 & 1993 & Czech Rep & Lysina, Pluhův Bor & 0.5 & 1 & 5 & NR & Frame grid \\
\hline Kulmatiski et al., 2003 & $1997-8$ & CT & Yale-Meyers Forest & 0.25 & & 18 & & Frame grid \\
\hline Lyford, 1964 & NR & MA & Harvard Forest & $\sim 1$ & & 4 & & straight-edge \\
\hline Neurath, 2011 & 2010 & $\mathrm{NH}$ & Bartlett Exp. Forest & 0.5 & 6 & 18 & NR & Frame grid \\
\hline Oulehle et al., 2006 & 1994, 2003 & Czech Rep & Načetín & 0.5 & 1 & 10 & $\sim 5$ & Frame grid \\
\hline Oulehle et al., 2010 & 2007 & Ukraine & Transcarpathian Mtns & 0.5 & 2 & 12 & NR & NR \\
\hline Rau et al., 2009 & 2005 & NV & Underdown Canyon & 0.25 & 8 & 24 & 3 & calc from BD \\
\hline Richter et al., 1989 & NR & $\mathrm{NC}$ & Black Mtns & 0.06 & 9 & 36 & NR & Measuring, displacement \\
\hline Ross, 2006 & 2005 & Mongolia & Hovsgol ILTER & 0.5 & 4 & 12 & 8.3 & Frame grid \\
\hline Schroth et al., 2007 & NR & VT & arsh-Billings Rockefeller Nat. Park & 0.5 & 6 & 18 & NR & NR \\
\hline Silver et al., 1994 & 1990 & PR & Luquillo LTER & 0.25 & & 8 & & NR \\
\hline Silver et al., 2000 & NR & Brazil & Tapajos Nat. Forest & $1-3$ & & 23 & 0.02 & NR \\
\hline Ussiri and Johnson CE, 2007 & 1998 & $\mathrm{NH}$ & W5, Hubbard Brook Exp. Forest & 0.5 & & 60 & 2.6 & Frame grid \\
\hline Wibiralske et al., 2004 & $1992-3$ & PA & Monroe and Carbon Counties & 0.25 & 5 & 62 & NR & Frame \\
\hline Zummo and Friedland, 2011 & 2009 & $\mathrm{NH}$ & Bartlett Exp. Forest & 0.5 & 4 & 16 & NR & Frame grid \\
\hline This study & 2003 & $\mathrm{NH}$ & White Mtn. Nat. Forest & 0.5 & 6 & 18 & $\sim 6$ & Frame grid \\
\hline This study & 2004 & $\mathrm{NH}$ & Bartlett Exp. Forest & 0.5 & 6 & 18 & 4 & Frame grid \\
\hline
\end{tabular}

$\mathrm{NR}=$ not reported

\section{Appendix supplementary references}

Austin, K. 2006. The Intersection of Land Use History and Exurban Development: Implications for Carbon Storage in the Northeast. Providence, RI: Brown University, MA Thesis.

Bedison, J.E., and A.H. Johnson. 2009. Controls on the Spatial Patterns of Carbon and Nitrogen in Adirondack Forest Soils along a Gradient of Nitrogen Deposition. Soil Science Society of America Journal 73(6): $2105-2117$.

Bedison, J.E., and A.H. Johnson. 2010. Seventy-Four Years of Calcium Loss from Forest Soils of the Adirondack Mountains, New York. Soil Science Society of America Journal 74(6): 2187-2195. 
David, M.B., M.J. Mitchell, and T.J. Scott. 1987. Importance of biological processes in the sulfur budget of a northern hardwood ecosystem. Biology and Fertility of Soils 5(3): 258-264.

Diochon, A.C., and L. Kellman. 2008. Natural abundance measurements of 13C indicate increased deep soil carbon mineralization after forest disturbance. Geophysical Research Letters 35(14): 1-5.

Fernandez, I.J., L.E. Rustad, S.A. Norton, J.S. Kahl, and B.J. Cosby. 2003. Experimental Acidification Causes Soil BaseCation Depletion at the Bear Brook Watershed in Maine. Soil Science Society of America Journal 67: $1909-1919$.

Friedland, A.J., E.K. Miller, J.J. Battles, and J.F. Thorne. 1991. Nitrogen deposition, distribution and cycling in a subalpine spruce-fir forest in the Adirondacks, New York, USA. Biogeochemistry 14(1): 31-55.

Gaudinski, J.B., S.E. Trumbore, E.A. Davidson, and S. Zheng. 2000. Soil carbon cycling in a temperate forest: radiocarbon-based estimates of residence times, sequestration rates and partitioning of fluxes. Biogeochemistry 51: 33-69.

Harrison, R.B., A.B. Adams, C. Licata, B. Flaming, G.L. Wagoner, P. Carpenter, and E.D. Vance. 2003. Quantifying Deep-Soil and Coarse-Soil Fractions: Avoiding Sampling Bias. Soil Science Society of America Journal 67: 16021606.

Hofmeister, J., F. Oulehle, P. Krám, and J. Hruška. 2008. Loss of nutrients due to litter raking compared to the effect of acidic deposition in two spruce stands, Czech Republic. Biogeochemistry 88(2): 139-151.

Hooker, T.D., and J.E. Compton. 2003. Forest Ecosystem Carbon and Nitrogen Accumulation During the First Century After Agricultural Abandonment. Ecological Applications 13(2): 299-313.

Huntington, T.G., and D.F. Ryan. 1990. Whole-tree harvesting effects on soil nitrogen and carbon. Forest Ecology and Management 31: 193-204.

Huntington, T.G., C.E. Johnson, A.H. Johnson, T.G. Siccama, and D.F. Ryan. 1989. Carbon, organic matter, and bulk density relationships in a forested Spodosol. Soil Science 148(5): 380-386.

Johnson, D.W., J.D. Murphy, R.F. Walker, D.W. Glass, and W.W. Miller. 2007. Wildfire effects on forest carbon and nutrient budgets. Ecological Engineering 31: 183-192.

Johnson, K.D., F.N. Scatena, A.H. Johnson, and Y. Pan. 2009. Controls on soil organic matter content within a northern hardwood forest. Geoderma 148(3-4): 346-356.

Krám, P., J. Hruška, B.S. Wenner, C.T. Driscoll, and C.E. Johnson. 1997. The Biogeochemistry of Basic Cations in Two Forest Catchments with Contrasting Lithology in the Czech Republic The biogeochemistry of basic cations in two forest catchments with contrasting lithology in the Czech Republic. Biogeochemistry 37(2): 173-202.

Oulehle, F., R. Hleb, J. Houska, P. Samonil, J. Hofmeister, and J. Hruska. 2010. Anthropogenic acidification effects in primeval forests in the Transcarpathian Mts., western Ukraine. Science of the Total Environment 408(4): 85664.

Oulehle, F., J. Hofmeister, P. Cudlín, and J. Hruška. 2006. The effect of reduced atmospheric deposition on soil and soil solution chemistry at a site subjected to long-term acidification, Nacetín, Czech Republic. The Science of the total environment 370(2-3): 532-44.

Ross, N. 2006. Soil Organic Carbon at Lake Hovsgol, Mongolia: The Role of Grazing and Permafrost. Providence, RI: Brown University, BS Thesis.

Schroth, A.W., A.J. Friedland, and B.C. Bostick. 2007. Macronutrient Depletion and Redistribution in Soils under Conifer and Northern Hardwood Forests. Soil Science Society of America Journal 71(2): 457-468.

Silver, W.L., J.C. Neff, M. McGroddy, E. Veldkamp, M. Keller, and R. Cosme. 2000. Effects of Soil Texture on Belowground Carbon and Nutrient Storage in a Lowland Amazonian Forest Ecosystem. Ecosystems 3(2): 193209.

Silver, W.L., F.N. Scatena, A.H. Johnson, T.G. Siccama, and M.J. Sanchez. 1994. Nutrient availability in a montane wet tropical forest: spatial patterns and methodological considerations. Plant and Soil 164(1): 129-145.

Ussiri, D.A.N., and C.E. Johnson. 2007. Organic matter composition and dynamics in a northern hardwood forest ecosystem 15 years after clear-cutting. Forest Ecology and Management 240(1-3): 131-142.

Zummo, L.M., and A.J. Friedland. 2011. Soil carbon release along a gradient of physical disturbance in a harvested northern hardwood forest. Forest Ecology and Management 261(6): 1016-1026. 